\title{
The Unintended Consequences of the Launch of the Single Supervisory Mechanism in Europe
}

\section{Franco Fiordelisi ${ }^{\mathrm{a} 1}$, Ornella Ricci ${ }^{\mathrm{a} 2}$ and Francesco Saverio Stentella Lopes $^{\mathrm{a} 3}$}

JEL classification: G21, G28

Keywords: Banking, Supervision; Regulation, Lending, Risk-taking.

a1 franco.fiordelisi@ uniroma3.it: University of Rome III, Faculty of Economics, 00145, Rome.

a1 F.Fiordelisi@mdx.ac.uk: Middlesex Business School, London NW4 4BT, U.K.

a2 ornella.ricci@ uniroma3.it: University of Rome III, Faculty of Economics, 00145, Rome.

${ }^{a 3}$ s.s.lopes@bangor.ac.uk : Bangor Business School, Bangor LL57 2DG, U.K.

\section{Acknowledgments}

We thank an anonymous referee and the editor, Stephen J. Brown, Thorsten Beck, Emilia

Bonaccorsi di Patti, Santiago Carbo, Francesco Columba, Federico Cecconi, Giovanni Cerulli,

Roy Cerqueti, Vincenzo Chiorazzo, Giorgio Di Giorgio, Olivier de Jonghe, Mauro Grande,

Iftekhar Hasan, Roman Matousek, Phil Molyneux, Enrico Onali, Marco Pagano, Bianca Potì,

Sabrina Pucci, Giovanni Puopolo, Klaus Schaeck, Enrico Sette, Gaetano Spartà, Amine Tarazi,

Anjan Thakor, and conference and seminar participants at the Financial Intermediation Network

of European Studies, Banca d'Italia, CNR-GRAPE, and Durham Business School for helpful comments. 


\begin{abstract}
The launch of the Single Supervisory Mechanism (SSM) was an historic event. Beginning in Nov. 2014, the most significant banks came under the direct supervision of the European Central Bank, while national supervisory authorities maintained direct supervision of the remaining banks. Thus, supervision is conducted on two levels, which could cause inconsistency problems. Did the behavior of the significant banks differ from that of the less significant banks during the SSM launch? We find that the significant banks reduced their lending activity more than the less significant banks did in order to shrink their balance sheets and increase their capitalization.
\end{abstract}

\title{
I. Introduction
}

Incomplete regulation and ineffective supervision were among the primary drivers of the 2009 Eurozone financial crisis (U.S. Financial Crisis Inquiry Commission (2011), Barth, Caprio, and Levine (2013)). In fall 2012, the European Commission, recognizing the need to reshape the supervision of banks, proposed an historic change in the European banking supervision system by creating a Single Supervisory Mechanism (SSM) led by the European Central Bank (ECB).

Effective Nov. 4, 2014, the SSM transferred the regulatory and institutional framework responsible for safeguarding the robustness and stability of the Eurozone banking industry to the European level. In short, the 130 most important banks in 19 countries (representing assets worth $€ 22$ trillion, i.e., $82 \%$ of the total banking assets in the Eurozone) now fall under the direct supervision of the ECB, and national supervisory authorities (NSAs) directly supervise the remaining banks in collaboration with the ECB. 
Although the SSM is a unique system, day-to-day supervision is conducted on two different levels within a complex supervisory system that could potentially produce regulatory arbitrage conditions. Thus, even though the SSM is designed to reduce variation in how the NSAs implement policies, supervisory inconsistency between the ECB and the NSAs is still possible. Agarwal, Lucca, Seru, and Trebbi (2014a) provide empirical evidence that the U.S. dual supervisory mechanism inconsistently implements identical rules due to differences in institutional design and incentives, which can adversely impact regulatory effectiveness. The authors show that state-level banking supervisors are more lenient than federal bank supervisors, and U.S. banks anticipate this difference in the strictness of supervision by adjusting their loan quality and leverage ratios. Similarly, European banks may perceive NSAs as more lenient than the ECB and thus may have adjusted their lending behavior during the SSM launch period.

This paper explores whether, in the run-up to the SSM's implementation, the significant European banks that expected to fall under direct ECB supervision (here referred to as "treated" banks) acted differently from smaller banks that expected to remain under direct NSA supervision (here referred to as "untreated" or "non-treated" banks). We focus on the banks' lending activity because the SSM's first step was to run a comprehensive assessment (CA) to reevaluate the banks' lending portfolios. The CA focused on evaluating banks' lending activity ${ }^{1}$ to

\footnotetext{
${ }^{1}$ Although the stress test was designed to incorporate liquidity, interest rate, and market risks related to security holdings, the CA carried out by the ECB and NSAs mainly focused on credit risk. Specifically, the CA i) reviewed over 800 specific loan portfolios (57\% of the banks' Risk Weighted Assets, RWA) involving more than 119,000 borrowers and approximately 170,000 collateral items; ii) built 765 models to "challenge" the banks' own estimates of collectively assessed provisions; iii) developed over 100 models to assess the banks' Credit Valuation Adjustment (CVA) calculations; and iv) revaluated over 5,000 of the most complex fair value exposures and over 100 complex valuation models. As noted by the ECB (European Central Bank (2014)), this process yielded total adjustments to asset carrying values of $€ 47.5$ billion due to i) additional provisions resulting from non-performing, non-retail debtors (individually assessed, working on an exposure-by-exposure basis); ii) additional provisions identified through the collective provisioning assessment of all performing exposures and non-performing retail exposures; and iii)
} 
ensure sound capitalization of the significant banks; thus, we expect that those banks modified their lending activities to reduce the scope of the ECB assessment and decrease the probability of capital shortfalls. Interestingly, banks were advised in advance about the lending focus of the CA. Eight months before the CA launch, the vice president of the ECB publicly anticipated how the CA would be implemented:

"These comprehensive reviews will provide transparency into the composition and credit quality of banks' loan portfolios, in the spirit of asset quality reviews. Such financial due diligence will furthermore inform about provisioning and loss mitigation policies and broadly validate banks' reporting" (Vítor Constâncio’s speech on Feb. 12, 2013, at the 2nd FIN-FSA Conference on EU Regulation and Supervision).

Thus, if the significant banks perceived the NSAs to be more lenient overall than the $\mathrm{ECB}$, they may have started to adjust their lending behavior to anticipate the CA for the SSM launch: thus, we expect that the banks' lending behavior may have been affected by the launch of the SSM.

We show that banks under the ECB's direct supervision (treated banks) reduced their lending activities more than other banks (untreated banks) did during the period of the launch of the SSM. We divide total loans into net loans and reserves for loan losses (i.e., the expected loss on the lending portfolio) and find that treated banks reduced both, suggesting that during the SSM launch period, treated banks reduced both the amount of loans provided and the quantity of money put aside to cover expected credit losses lending to higher quality borrowers in

impacts from the fair value exposures review (including non-derivative revaluations, CVA adjustments, and adjustments to derivative pricing models). The last component, referred to as security holdings, accounted for only $€ 4.6$ billion (i.e., less than $10 \%$ of the total impact). 
comparison of untreated banks. This behavior resulted in a sizable increase in the banks' equity capital ratios without a corresponding increase in equity capital levels.

We further explore our results by country. We find that treated banks uniformly decreased their lending activities, but there are differences across countries in the growth of reserves for credit losses and in the increase in the capital ratios of the treated banks. Specifically, the reserves for loan losses of French and Italian banks decreased less than the reserves of the other treated banks, and as a result, the capital ratios of French and Italian treated banks were less affected by the launch of the SSM. Overall, our results provide evidence that banks strategically adjusted their lending activities during the SSM launch period in an attempt to increase their capital ratios without raising new equity capital.

Our results stand up to various robustness checks. First, we do not observe such differences between treated and untreated banks in 2012, the year before the SSM launch was announced. Second, we do not find statistically significant differences in other banks' outputs, such as other earning assets. Third, we apply the ECB selection criteria to countries outside the European Monetary Union (EMU), that is, banks that were not involved in the SSM launch, and we find no evidence of a decrease in the loan supply for large banks outside the SSM scope. Fourth, we conduct a matching analysis focusing only on large banks to show that our results are qualitatively unaffected by the selected mechanism operated by the ECB.

The main contribution of our paper is that it provides new insights into how banks' lending practices changed in anticipation of the SSM launch. Specifically, we argue that banks perceived the NSAs to be more lenient than the ECB, and we provide empirical evidence that treated banks adjusted their lending activities and capital ratios in anticipation of the SSM in an attempt to reduce the probability of costly capital adjustments after the ECB's CA. 
The remainder of the paper is structured as follows. First, we review previous studies and develop our research hypotheses (Section II). Second, we describe our data (Section III) and identification strategy (Section IV). We then run a preliminary inspection (Section V) and discuss our main results (Section VI) and falsification tests (Section VII). Conclusions are drawn in Section VIII.

\section{Literature, Contribution, and Hypotheses}

A large stream of literature analyzes the impact of regulation on banks' behavior by focusing on various issues such as lending (e.g., Li, Nandy, and Roberts (2012), Carlson, Shan, and Warusawitharana (2013), Ongena, Popov, and Udell (2013), Agarwal, Amromin, BenDavid, Chomsisengphet and Evanoff (2014b)), and Lepetit, Saghi-Zedek, and Tarazi (2015)), risk-taking (e.g., Fiordelisi, Marques-Ibanez, and Molyneux (2013), Harris and Raviv (2014)), equity issues (Dinger and Vallascas (in press)), economic growth (Jayaratne and Strahan (1996), Kroszner and Strahan (1996), and Berger and Hannan (1998)), and banking competition (Calderon and Schaeck (in press)) as well as developing financial sectors around the world (e.g., Levine, Loayza, and Back (2000), Barth, Caprio, and Levine (2004)).

Surprisingly, only a few papers empirically examine banks' reactions to different types of supervision, even though the literature on supervisory design is well established (spanning from its early public interest roots in Pigou (1938) to the Chicago theory of Stigler (1971) and Peltzman (1976)). One stream of the empirical literature focuses on regulatory arbitrage (Rosen (2003), (2005), Rezende (2014), and Karolyi and Taboada (2015)) by showing that banks actively shop, through various channels (e.g., charter changes, mergers, and location changes), for regulators who are likely to be softer on them. Focusing on the U.S. supervisory mechanism, 
a few papers offer empirical evidence on the optimal supervisory structure. For example, Peek, Rosengren, and Tootell (1999) show that bringing supervisory responsibilities and monetary policy under a single authority can be beneficial because confidential bank information can help the supervisory board's staff more accurately forecast important macroeconomic variables. Agarwal et al. (2014a) empirically analyze the effect of the U.S. dual supervisory system by exploiting a legally determined rotation policy that assigns U.S. federal and state supervisors to the same banks at exogenously predetermined time intervals. The authors show large and significant differences in how regulators implement identical rules due to differences in their institutional design and incentives.

A second stream of the literature examines the effect of stress tests performed by supervisory authorities. Focusing on the United States, Morgan, Peristiani, and Savino (2014) find that the 2009 stress test conducted on the 19 largest U.S. bank holding companies produced valuable information for the market. Before the results were disclosed, investors had already identified weak banks, but with the publication of the results, they gained information about the size of the capital gap and learned that banks with larger gaps experienced more negative abnormal returns. Acharya and Steffen (2014) compare the capital shortfall measured by regulatory stress test (conducted both in Europe and the United States) to that of a benchmark methodology that employs only publicly available market data. This alternative methodology assumes a crisis scenario that is defined by a $40 \%$ drop in the market equity index over six months (see Acharya, Engle, and Richardson (2012)). The results show that regulatory stress tests could be more effective using capital adequacy definitions based on total assets and market risks rather than risk-weighted assets. 
Not surprisingly, very few papers examine the effect of the SSM on banks' behavior, as the SSM launch was particularly rapid. These papers mostly focus on the market reaction to the CA results. According to the Bank of Italy:

"The share prices of the banks for which capital strengthening requirements emerged recorded large losses owing to the dilution effect of any capital increases. The risk premiums on the CDS of almost all the banks involved in the exercise narrowed in the days immediately following 26 October, reflecting increased confidence on the part of investors; these improvements were subsequently scaled back" (Banca d'Italia (2014), p. 31). conducted both in Europe and the U.S

Our paper takes a very different perspective, as we analyze banks' reactions to the SSM launch. The SSM transferred the regulatory and institutional framework responsible for safeguarding the robustness and stability of the Eurozone banking industry to the European level beginning in Nov. 2014.

Although the European Banking Authority (EBA) was established in 2011 to ensure appropriate, efficient, and harmonized European regulation and supervision for all banks, NSAs' supervision of banks varied substantially until Nov. 2014. The EBA launch in 2011 was not followed by an automatic harmonization of supervisory practices, as noticed by the same EBA in 2015 when analyzing the internal-rating-based (IRB) models validated by different NSAs in Europe. Specifically, the EBA noted that

"The actual implementation of the IRB models has however led to a lack of 
comparability and substantial divergences across banks in terms of model outcomes, where not all differences appear to be justified by risk-based drivers. A substantial share of the variation in model outcomes and subsequently risk-weighted exposure amounts is caused by non-risk-based drivers, such as differences in definitions and modeling choices” (European Banking Authority (2015), p. 8).

Thus, the SSM aimed to reduce the heterogeneity of the NSAs' behavior, and, consequently, it was designed to be unique and consistent for all banks. The answers to the FAQ relative to the legislative package for banking supervision in the Eurozone ${ }^{2}$ states:

"While the SSM will cover all banks in the Euro zone, national supervisors will have responsibility for day-to-day supervision of less significant banks. However, the ECB may at any moment decide to directly supervise one or more credit institutions to ensure consistent application of high supervisory standards. The work of national supervisors is integrated into the Single Supervisory Mechanism: for instance, the ECB will send general instructions to national supervisors, and national supervisors have a duty to notify the ECB of supervisory decisions of material consequence."

While the consequences of switching from a multiple supervisory mechanism (based on NSAs) to the SSM system should be visible in the medium to long run, we analyze the reactions during the SSM launch period (i.e., 2013-2014). We argue that banks anticipated the SSM launch and adjusted their lending behavior to shrink their balance sheets in an attempt to increase

\footnotetext{
${ }^{2}$ Available at the following link: http://europa.eu/rapid/press-release MEMO-13-780_en.htm.
} 
their capital ratios. Based on Agarwal, Lucca, Seru, and Trebbi (2012), we expect that banks were not passive during the changeover process but instead may have adjusted their lending activities and capitalization in anticipation of the SSM launch. Thus, the critical point to identify is when European banks knew whether they would be treated or not. The SSM operational launch was publicly announced on Sept. 12, 2012, when the European Commission adopted two proposals for the establishment of a single supervisory mechanism (SSM) for banks led by the European Central Bank (ECB). Just a few days earlier on Sept. 7, Vítor Constâncio (2012), vice president of the ECB, referred in a public speech to direct supervision only for the significant cross-border banking groups.

Later that year, in Dec. 2012, the Economic and Financial Affairs Council (ECOFIN (2012)) reached a landmark agreement on the SSM that established the following criteria that the ECB would use to identify "significant" banks: the total value of a bank's assets exceeds 30 billion euro, or the ratio of its total assets to the GDP of the participating Member State of establishment exceeds $20 \%$, unless the total value of assets is below 5 billion euro, or following a notification from their respective competent national authority considering the institution of significant relevance for the domestic economy, the ECB confirms such significance following a comprehensive assessment of that credit institution by the ECB, including a balance-sheet assessment. In the following months, Vítor Constâncio (2013) talked about the SSM on various occasions, and he previewed how the CA would be implemented in a speech on Feb. 12, 2013. We argue that from the beginning of 2013, banks were able to identify whether they would fall under direct ECB supervision and that the ECB would pay great attention to the lending portfolios of treated banks after the launch of the SSM. Consequently, banks began 
adjusting their balance sheets from the first quarter of 2013 through Oct. 2014, when the results were disclosed.

\section{Data}

We collect annual data on banks' financial statements from the Bankscope database. We focus on banks in the Eurozone that were affected by the SSM launch. ${ }^{3}$ In our sample, "treated banks" are those that fell under the ECB's direct supervision after the SSM launch, and the remaining banks are "untreated" (i.e., under the direct supervision of NSAs). We use as a control sample all banks ${ }^{4}$ that have a consolidated balance sheet available in Bankscope and that are headquartered in the Euro area. We exclude from the analysis very small banks, banks with a very low lending orientation, ${ }^{5}$ and banks that were nationalized after the recent financial crisis. We do not use as controls banks whose principal shareholder is also the main shareholder of a treated bank. The resulting sample spans from 2011 to 2014 and comprises 336 banks in the Euro area: 103 are treated, and 233 are untreated.

Table 1 summarizes all of the variables used in our empirical analysis, and Table 2 reports the summary statistics.

\section{$<$ INSERT TABLES 1 and 2>>}

\footnotetext{
${ }^{3}$ We exclude banks headquartered in Luxembourg because they have a different business model than banks located in the rest of the Euro area.

${ }^{4}$ We exclude from the control sample securities firms, group finance companies, investment and trust corporations, clearing institutions, and custody and investment banks.

${ }^{5}$ Specifically, the ECB assessment was focused on the lending activity of large banks, so we exclude from our sample banks in the bottom fifth percentile of the distribution of total assets and banks in the bottom fifth percentile of the distribution of the ratio of total loans to total assets. None of our results are qualitatively affected by including these banks in our analysis.
} 
Table 2 shows that European banks (both treated and untreated) increased their lending activities, their reserves for loan losses, and their equity capital during the 2011-2014 sample period. On average, total loans increased by $3.6 \%$, reserves for loan losses by $13.6 \%$, net loans by $3.1 \%$, and equity capital by $7.0 \%$.

\section{Identification Strategy}

We use a difference-in-difference estimation framework to investigate whether treated banks adjusted their lending activities differently than untreated banks around the period of the SSM launch. We focus on banks' lending activity, specifically the growth of loans, loan loss reserves, capital ratios, and equity capital holdings. We then run several falsification tests. First, we examine how banks' other earning assets changed during the SSM launch period. Second, we look for any significant differences between the treated and untreated samples in 2012, the year prior to the SSM announcement. Third, we check whether large banks headquartered in countries outside of the Eurozone behaved similarly to those in our sample. Fourth, to ensure that the ECB's selection criteria are not driving our results, we use a matching algorithm to compare the outcome variables of treated banks with those of their closest neighbors in terms of size and geographic location.

The difference-in-difference estimator relies on two primary assumptions. First, the selection of treated banks must be orthogonal with respect to our main outcome variables. Second, we need to show that the parallel trend assumption between the treated and untreated samples is stable. In the next sections, we provide evidence that both of these assumptions hold, even though the ECB's selection criteria are far from random. Hence, we can identify the causal effect of the SSM on banks' lending portfolios by estimating the following regression model: 


$$
\mathrm{Y}_{i, t}=\alpha+\beta w_{i, t}+\gamma \mathrm{X}_{i, t-1}+\mathrm{A}_{i}+\mathrm{B}_{t}+\varepsilon_{\mathrm{i}, \mathrm{t}}
$$

where the dependent variable (Y) is one of the following variables measured at time $t$ for bank $i$ : i) gross loan growth (L_GR); ii) the growth of loan loss reserves (RLL_GR); iii) net loan growth (NL_GR); iv) the equity to total assets ratio (ETA); or v) equity capital growth (E_GR). As a robustness check, we also use as a dependent variable the growth of other earning assets (OEA_GR).

In our main models, we include bank fixed effects (A) and year dummy variables (B). There are several potential explanations for why treated banks (under the SSM) reduced their lending to a larger extent than did untreated banks despite the SSM, including a higher need for deleveraging and greater diversification compared to smaller banks. In addition, many of the treated banks are Global Systemically Important Financial Institutions (G-SIFIs) and are subject to more stringent capital requirements. However, these alternative explanations rely on differences between banks that are largely persistent over time, especially in a relatively short time horizon such as the period from 2011 to 2014 . Therefore, by using bank fixed effects, we also rule out the above alternative explanations. In all of our specifications, the vector X captures time-varying banklevel control variables, including bank size, the variable on which the ECB based its selection of treated banks.

Our coefficient of interest is $\beta$ for the dummy $w_{i t}$, which equals 1 for banks under the scope of the CA after banks became aware of the SSM launch (i.e., from 2013 onward) and 0 otherwise (i.e., up to 2012). The slope $\beta$ provides information about the causal effect of the SSM launch on bank behavior: a positive coefficient indicates a positive causal effect on our outcome 
variables, whereas a negative slope signals that the SSM had a negative causal effect on our outcome variables.

We run each model three times: in the first run, we use only bank size as a control variable. In the second, we add a vector of control variables, including capitalization, cost efficiency, and profitability. Finally, in the third model, we include all control variables and country-year dummies to rule out the possibility that time-varying heterogeneity at the country level affects our results.

\section{Preliminary Inspection}

The difference-in-difference estimator relies on two main assumptions: the treatment must be orthogonal with respect to the outcome variables, and treated and untreated banks must satisfy the parallel trend assumption. In this section, we provide evidence to support both of these assumptions. Figure 1 depicts the average loan growth from 2010 to 2012 for the treated and untreated banks. The average difference in the growth of loans was constant in the pretreatment period, ${ }^{6}$ indicating that the parallel trend assumption holds and that our estimator can show causal effects of the SSM launch on the lending supply. However, because the ECB's selection criteria for the treated banks was not random and was based on bank size, the two groups may differ in important ways. To gain further insight into how the samples of treated and untreated banks differ over time, we focus on their observable characteristics. Table 3 reports the year-by-year differences between the two groups of banks and their statistical significance (pvalues).

\footnotetext{
${ }^{6}$ The stability of the difference in loan growth in the pretreatment period is formally tested in Section VII.B. The results reported in Table 9 indicate no change between 2011 and 2012 in average loan growth between treated and untreated banks.
} 


\section{$<<$ INSERT TABLE 3>>}

Table 3 shows that the difference in gross and net loan growth between the two groups of banks widened substantially during the period of the SSM launch. In 2011 and 2012, before the SSM was implemented, the difference in the growth of loans between the two groups was stable and not statistically distinguishable from 0 , but it expanded during the treatment period and became highly statistically significant. We see a similar pattern in the growth of loan loss reserves. Table 3 also shows that the difference in capital ratios (measured as equity to total assets) between treated and untreated banks narrowed during the treatment period, but the difference between the two groups of banks in the growth of equity remained statistically indistinguishable from 0 throughout the sample period.

This evidence suggests that overall, treated banks decreased their lending activities and increased their capital ratios during the period of the SSM launch. As expected, treated banks were larger in terms of total assets than untreated banks. The difference in size also decreased during the treatment period, suggesting that banks may have tried to decrease their asset size, thereby increasing their capital ratios.

\section{Main Results}

Tables 4 and 5 report the results for the difference-in-difference model (1). Our coefficient of interest is always estimated for the treatment variable $w$, which equals 1 for treated banks in the years when banks were aware of the SSM launch (i.e., 2013 onward) and 0 otherwise (i.e., untreated banks at any time and treated banks up to 2012). This coefficient provides information about the causal effect of the SSM launch: A positive coefficient suggests 
an increase in the outcome variable, whereas a negative slope signals a decrease in the outcome variable.

\section{A. The Effect of the SSM on Banks' Lending Behavior}

Table 4 reports the effect of the SSM launch on banks' lending behavior. We find that treated banks reduced their lending activities as soon as they realized that they would be treated. Specifically, the coefficient estimate for the treatment variable $(W)$ is negative and statistically significant in columns 1 to 3, where the dependent variable is the growth of loans (L_GR). To rule out the possibility that our results are driven by country-specific transitory shocks, we add country-year dummy variables in column 3. The coefficient on our treatment variable remains negative and statistically significant (at $1 \%$ or less), implying that our results are not driven by country-specific shocks. These results are also economically meaningful, indicating that the SSM launch decreased the loan supply by $4.63 \%$ to $5.03 \%$. As expected, the treatment effect is not affected by adding banks' characteristics to our regression model. In columns 2 and 3, we add bank characteristics (capitalization, cost efficiency, and profitability) as control variables, and the treatment effect remains negative and statistically significant.

\section{$<$ INSERT TABLE 4 >>}

Because total loans includes the expected loss on the banks' lending portfolio (the reserves for loan losses), the decline in lending activities reported in the first three columns of Table 4 may be driven by a decline in expected credit losses. Specifically, if banks perceived the ECB to be a stricter regulator, they may have improved the quality of their lending portfolio, thus 
decreasing expected credit losses without necessarily affecting the growth of net loans (the growth of total loans net of the reserves for loan losses).

To examine this possibility, we split total loans into two components: reserves for loan losses and net loans. Doing so allows us to test whether the decline in loan supply was driven entirely by a decrease in the expected credit losses, which could have important policy implications. Columns 4-6 in Table 4 report the results from our difference-in-difference model using as the dependent variable the growth of loan loss reserves and the growth of net loans.

We find that expected loan losses declined during the treatment period. Specifically, the coefficient on our treatment variable $(W)$ is negative and statistically significant in all of our specifications, indicating that banks indeed held back their reserves for loan losses during the treatment period in anticipation of lower credit losses. The treatment effects reported in Table 4, columns 4 to 6, are also economically meaningful: the SSM launch decreased the growth of the reserves for loan losses by $19.14 \%$ (column 4). When we control for additional bank characteristics and add country-year fixed effects in columns 5 and 6, respectively, we find that the SSM launch decreased the growth of the reserves for loan losses by $17.1 \%$ and $14.4 \%$, respectively.

To rule out the possibility that the decrease in loan supply (shown in columns 1-3 of Table 4) is entirely driven by the decrease in the growth of reserves for loan losses (columns 4-6 of Table 4), we rerun the regression using the growth of net loans (i.e., the growth of gross loans without the reserves for loan losses) as the dependent variable (columns 7-9 of Table 4). The treatment effect is still negative and statistically significant, suggesting that the decrease in loan supply is only partially driven by the decrease in the growth of loan loss reserves. 
In sum, we show that treated banks decreased their lending activities, suggesting that they reduced the amount of money loaned out. This outcome could have been achieved by banks reinvesting only part of their cash inflows from repaid loans to grant new loans. In addition, this section showed that treated banks decreased their reserves for loan losses more than untreated banks did during the SSM launch period, suggesting an improvement in the quality of the lending portfolios of treated banks (i.e., treated banks expected lower credit losses in the future, which could have been achieved by reducing lending to less credit-worthy borrowers). Our findings suggest that the credit crunch (especially for borrowers classified by treated banks as less credit worthy) may have been an unintended consequence of the SSM launch.

\section{B. The SSM Effect on Lending Activities: Capital Ratios}

The previous sections provide empirical evidence that treated banks reduced their lending activities and their reserves for credit losses more than untreated banks did in anticipation of the SSM launch. A potential explanation for these actions is that treated banks were afraid of potential capital shortfalls following the announcement of the ECB's new evaluation practices and tried to increase their capital ratios by shrinking their balance sheets through a reduction in lending activities. We thus ask the following question: ${ }^{7}$ Did the decrease in lending activities enable treated banks to increase their capital ratios? To answer this question, we rerun our difference-in-difference model but use two measures of capital holdings as the dependent variable: the ratio of total equity to total earning assets and the growth of equity capital. Table 5 presents the results.

The first three columns of Table 5 show a positive and statistically significant (at $5 \%$ or less) treatment effect on banks' capital level (i.e., the ratio of equity to total earning assets).

\footnotetext{
${ }^{7}$ We thank the referee for suggesting that we run a follow-up test by extending our analysis on the effect of the SSM on capital ratio changes.
} 
Columns 4-6 indicate that treated and untreated banks exhibited no difference in equity growth during the period of the SSM launch. Specifically, the treatment effect on equity growth is positive but not statistically distinguishable from 0 . This result indicates that the increase in capital ratios was caused by a reduction in the size of the treated banks. We therefore conclude that in the run-up to the SSM launch, treated banks decreased their lending activity more than untreated banks did in an attempt to shrink their balance sheets and increase their equity capital ratios.

\section{$<<$ INSERT TABLE 5 >}

The results reported in Table 5 are also economically meaningful. Treated banks increased their capital ratios by $0.72 \%$ (in column 1) in response to the SSM's introduction. Using the average capital ratio in our sample $(9.75 \%)$ as a benchmark, this value represents an increase of $7.38 \%$. The treatment effect is unaffected by adding profitability and cost efficiency as control variables in our analysis or by augmenting our models with country-year fixed effects. Specifically, the estimated treatment effects in columns 2 and 3 are, respectively, $0.78 \%$ and $0.73 \%$. Hence, this result is consistent with banks decreasing their lending activity and their reserves for loan losses to increase their capitalization. In the next section, we analyze the heterogeneity behind our main results. Specifically, we test whether banks operating in different countries reacted differently to the SSM launch.

\section{Bank-Level Heterogeneity in Response to the SSM Launch}


As shown in the previous sections, treated banks reduced their lending activity more than untreated banks did in anticipation of the SSM launch. Although we believe it is conceptually inaccurate to disentangle the CA from the SSM (because the CA was the first supervisory action carried out by the ECB within its direct supervisory role), here we empirically investigate whether treated banks were reacting to the CA "only" as a review and stress-test exercise or whether they were worried about the shift to ECB direct supervision because they perceived it as less lenient than the NSAs. Put differently, we investigate whether the lending reduction among treated banks was a window-dressing behavior for the CA exercise or whether it reflected a fear of more stringent supervision in the future. In the first case, treated banks would be worried that the publication of the CA results would allow for a quick comparison with their peers ("reputational effect") and with regard to the necessary recovery measures to cover the capital shortfall revealed by the exercise ("dilution effect"). In the second case, treated banks would be worried not only by the direct consequences of the CA exercise but by the upcoming change from NSA to direct ECB supervision.

Although it is not possible to disentangle the CA effect from that of the SSM (because the CA is part of the ECB's direct supervision), we can explore heterogeneity across treated banks and determine whether different subsamples of treated banks changed their lending activities in different ways in response to the SSM launch. More capitalized banks (those that obtained a better assessment in the CA exercise) would be less worried than their less capitalized peers about both the reputational and the dilution effects of the report. Consequently, if treated banks were only worried about the CA as a specific stress-test exercise and not about the future switch to direct ECB supervision, we should observe a non-significant reduction in loans among the banks that performed the best on the CA. Conversely, if treated banks were in a more uncertain 
situation and perceived the CA as the first step toward a more stringent supervisory system in the future, we should observe a more substantial reduction in lending among institutions that performed well on the CA.

Among the various measures of capitalization provided in the CA's final results, we focus on common equity tier 1 (CET1) after the CA in the adverse stress-test scenario. The minimum capital requirement requested by the ECB in the adverse scenario was 5.5\%. As shown in Figure 2, the capital buffer of treated banks varied widely: the ECB estimated that adverse economic conditions would leave some banks short of CET1 (less than 5.5\% in CET1), while some other treated banks would remain well capitalized. Based on this variable, we identify two subsamples of treated banks: the less capitalized treated banks (i.e., those with less than $5.5 \%$ of CET1 in the ECB's adverse scenario) and the most capitalized treated banks (i.e., those in the top decile of the CET1 distribution depicted in Figure 2). Using these definitions, we construct two dummies, as described in Table 1, and use them to augment our main models. Table 6 reports the results, which allow us to assess whether less capitalized and the most capitalized banks displayed differences in comparison to the other banks. This analysis also provides useful insights into the reasons behind the treated banks' reaction to the SSM launch.

\section{$<<$ INSERT TABLE 6>>}

Columns 1 and 3 of Table 6 show two important results. First, undercapitalized banks made more extreme adjustments before the SSM launch: the interaction between our treatment variable $(W)$ and the portion of undercapitalized banks (L_CAP) is negative and statistically significant (at the 5\% level or less), indicating that, as expected, undercapitalized banks 
decreased their loan supply more than the rest of the treated group leading up to the SSM launch. In contrast, the interaction between our treatment dummy and the portion of well-capitalized banks is not statistically distinguishable from 0 , indicating that well-capitalized banks reduced their lending activities in a manner similar to all treated banks.

Table 6 shows that the best performers in the CA, those that we expect would have been less worried by the reputational and dilution effects (i.e., the banks identified by the dummy M_CAP) of the stress-test exercise, significantly reduced their lending activity in amounts similar to the average of the treated group. Overall, these findings support the view that the reduction in lending among treated banks was not simply a case of window-dressing behavior in preparation for the CA exercise but instead represented a general expectation that the ECB's direct supervision would be less lenient than the NSAs' supervision in the past. Interestingly, Table 6 also shows that well-capitalized banks decreased their reserves for credit losses at a slower pace with respect to treated banks. Overall, this evidence confirms that less capitalized treated banks adjusted their lending activities more severely than the other treated banks during the period of the SSM launch.

\section{Country-Level Heterogeneity in Response to the SSM Launch}

In this section, we test whether the ECB's supervisory approach is similar to that of the NSAs with larger shares of ECB capital. ${ }^{8}$ We focus on the four largest subscribers of ECB capital: Deutsche Bundesbank (18\%), Banque de France (14\%) Banca d'Italia (12\%), and Banco de España $(9 \%) .{ }^{9}$ We interact the treatment variable with an indicator variable for each of these countries to test whether NSAs with larger capital shares had a stronger influence on the ECB's

\footnotetext{
${ }^{8}$ We thank the anonymous referee for suggesting that we run a follow-up test at the country level.

${ }^{9}$ https://www.ecb.europa.eu/ecb/orga/capital/html/index.en.html
} 
supervisory approach than other NSAs. If this were the case, we should find that German banks adjusted their lending activity the least, followed by French, Italian, and Spanish banks.

\section{$<<$ INSERT TABLE $7>>$}

Panel A of Table 7 reports the differences in the responses to the SSM launch of the French, German, Spanish, and Italian banks from those of the other treated banks. We do not find evidence of country heterogeneity in the treated banks' contraction of lending activities: the interaction coefficient is not statistically significant for any of the four countries analyzed. This result holds irrespective of using the growth of loans or the growth of net loans as the dependent variable. Thus, we conclude that all treated banks were afraid of a potential capital shortfall after the ECB assessment, and they decreased their supply of loans in an attempt to reduce the scope of the ECB CA and to shrink their balance sheets.

In Table 7, we also check for heterogeneous bank responses in terms of loan loss reserves. We find some variation in how the SSM launch affected the growth of loan loss reserves across countries: Columns 5 to 8 show a positive and statistically significant interaction effect for French and Italian banks, suggesting that the decline in the reserves for loan losses was substantially less pronounced in these two countries.

The country heterogeneity in the growth of the treated banks' loan loss reserves is also reflected in the adjustment of banks' capital ratios. As shown in Table 7, we find that Italian and French treated banks did not increase their capitalization during the period of the SSM launch. This result further confirms that the improvement in the quality of banks' lending portfolios allowed treated banks to preserve their capital by holding back their reserves. This strategy, 
accompanied by a decrease in the loan supply, allowed treated banks to increase their equity capital ratios in preparation for the SSM launch.

\section{Robustness Checks}

To further verify whether the effect on bank loans that we identify was exclusively due to the SSM launch, we run three placebo tests. First, we estimate the same models presented in Table 4 but for all other banking products other than the lending supply. Second, we estimate our models but pretend that the SSM launched in 2012. Third, we apply the ECB selection criteria to banks operating in countries outside of the Euro area, and we re-estimate all of our models to determine whether some of our results are simply driven by confounding factors leading the behavior of large banks. Fourth, we run a matching analysis based on size and estimate the difference in means between treated and control banks before and after the SSM launch to determine whether the differences in our main outcome variables are driven by bank size.

\section{A. A Falsification Test Changing the Scope of the SSM Launch}

In Table 8, we run a falsification test by estimating the treatment effect on bank products other than loans (i.e., the growth of other earning assets). Specifically, we re-estimate our difference-in-difference model using as the outcome variable the growth of other earning assets (OEA_GR) and the SSM launch (2013-2014) as the treatment period. We find that the coefficients estimated for the treatment variable $(W)$ are not statistically significant in all of the models, suggesting that the SSM launch did not have a statistically significant effect on banking activities other than lending among treated banks. 


\section{B. A Falsification Test Changing the Year of the SSM Launch}

In this section, we define as treated those banks that fell under direct ECB supervision when the SSM was introduced, but we run the model for all of our outcome variables over the years prior to the launch of the SSM, from 2011 to 2012, and we use 2012 as the treatment

period. Table 9 shows that the treatment effects $(W)$ estimated in the pretreatment period are not statistically significant in any of our models. This evidence reinforces the result reported in Figure 1, thus sustaining the parallel trend assumption needed for our difference-in-difference estimation.

\section{$<<$ INSERT TABLE 9>>}

\section{A Falsification Test Changing the Countries of the SSM}

We also run a falsification test by estimating the treatment effect on the countries not involved in the SSM launch. We use the ECB's selection criteria to identify banks that would have been treated if the SSM launch had involved countries outside of the Eurozone.

Specifically, we focus our attention on banks operating in Bulgaria, Croatia, the Czech Republic, Denmark, Hungary, Poland, Romania, Sweden, and the United Kingdom. We create a sample of pseudo-treated banks whose size (total assets) exceeds $€ 30$ billion, or that have a ratio of total assets to GDP greater than $20 \%$ and larger than $€ 5$ billion, or that are one of the three largest institutions in the country. 


\section{$<<$ INSERT TABLE 10〉>}

The results presented in Table 10 are consistent with our main analyses. Specifically, we do not find any effect on the banks operating in countries outside of the Euro area. The treatment effects are not significant regardless of whether we look at the banks' lending activities or their capitalization. This evidence further supports our previous results showing that the SSM launch had a causal effect on treated banks' lending activity.

\section{Further Control for the Selection Mechanism Operated by the European Central Bank}

In this section, we further explore potential concerns related to the ECB's selection criteria for "significant" banks. The ECB's selection of banks was not random but was based on some observable characteristics. These criteria mainly concerned bank size (total assets) and the relevance of a particular bank to the economy of its country of establishment. In our main tests, we took into account the sample selection by using the natural logarithm of total assets as a control variable in all of our regressions. In this section, we follow a different strategy and implement a matching analysis based on size and country of establishment. Specifically, each treated bank is matched each year based on the Euclidean distance from its closest neighbor, calculated based on bank size in 2012 (i.e., the natural log of total assets in 2012) and geographic location (a set of country indicator variables). We estimate the average treatment effect on treated banks using the bias-adjusted estimator defined in Abadie and Imbens (2006). Because our matching at the country level is not exact, we use bank size in 2012 and country dummies to adjust for any potential bias, following Abadie and Imbens. 


\section{$<<$ INSERT TABLE 11〉>}

Table 11 shows that our findings are qualitatively unaffected when we use this matching strategy. The results are consistent with those of our main analyses. The differences between treated and control banks in terms of loan growth, net loan growth, and the growth of reserves for loan losses are negative and statistically significant (at the 5\% level or less) during the treatment period. Somewhat surprisingly, the difference in the equity capital ratios in the treatment period is positive but not statistically distinguishable from 0 . While this evidence may seem to contradict the results reported in the main analyses, it probably simply arises from the heterogeneity at the country level shown in Section VI.D. Figure 3 also reports the size (natural logarithm of total assets) balance between treated and control banks resulting from the matching estimator. The figure shows that the matching algorithm substantially improves the balance in terms of size between treated and untreated banks; however, the two groups are still not perfectly balanced after the matching.

\section{Conclusions}

The establishment of the SSM was an historic event in the European banking industry. The most significant 130 banks in 19 countries fell under the ECB's direct supervision beginning on November 4, 2014, while the NSAs maintained direct supervision, in collaboration with the ECB, over the remaining banks.

Although the consequences of switching from a multiple supervisory mechanism (MSM) to a single supervisory mechanism (SSM) generally only become visible over the medium to long run, our analysis shows that banks had some immediate reactions to the announcement of 
the new SSM system. This paper aims to estimate banks' response to the first step of the SSM, the comprehensive assessment (CA) announced on Oct. 23, 2013, and completed on Oct. 26, 2014. We concentrate on banks' lending activity and their capitalization because these aspects were the main focus of the CA.

Our main finding is that banks under direct ECB supervision and involved in the CA reduced their lending activities more than untreated banks did in anticipation of the SSM launch. Our results are robust to various additional tests. For example, we do not observe such differences between treated and untreated banks before the SSM launch, and we do not find statistically significant differences in other bank products (other earning assets). These findings are particularly important for policy makers because they show that the credit crunch was an unintended consequence of the SSM launch. 


\section{References}

Abadie, A., and G. W. Imbens. "Large Sample Properties of Matching Estimators for Average Treatment Effects." Econometrica, 74 (2006), 235-267.

Acharya, V.; R. Engle; and M. Richardson. "Capital Shortfall: A New Approach to Ranking and Regulating Systemic Risks.” American Economic Review, 102 (2012), 59-64.

Acharya, V. V., and S. Steffen. "Falling Short of Expectations - Stress Testing the Eurozone Banking System.” Center of European Policy Studies Policy Brief No. 315 (2014).

Agarwal, S.; D. Lucca; A. Seru; and F. Trebbi. "Inconsistent Regulators: Evidence from Banking.” NBER Working Paper No. 17736 (2012).

Agarwal, S.; D. Lucca; A. Seru; and F. Trebbi. "Inconsistent Regulators: Evidence from Banking." Quarterly Journal of Economics, 129 (2014a), 889-938.

Agarwal, S.; G. Amromin; I. Ben-David; S. Chomsisengphet; and D. D. Evanoff. "Predatory Lending and the Subprime Crisis." Journal of Financial Economics, 113 (2014b), 29-52.

Banca d'Italia. Financial Stability Report No. 2/2014 (2014).

Barth, J. R.; G. Caprio Jr; and R. Levine. "Bank Regulation and Supervision: What Works Best?” Journal of Financial Intermediation, 13 (2004), 205-248.

Barth, J. R.; G. Caprio Jr; and R. Levine. "Bank Regulation and Supervision in 180 Countries from 1999 to 2011.” Journal of Financial Economic Policy, 5 (2013), 111-219.

Berger, A. N., and T. H. Hannan. "The Efficiency Cost of Market Power in the Banking Industry: A Test of the 'Quiet Life' and Related Hypotheses." Review of Economics and Statistics, 80 (1998), 454-465. 
Calderon, C., and K. Schaeck. "The Effects of Government Interventions in the Financial Sector on Banking Competition and the Evolution of Zombie Banks." Journal of Financial and Quantitative Analysis (in press).

Carlson, M.; H. Shan; and M. Warusawitharana. "Capital Ratios and Bank Lending: A Matched Bank Approach.” Journal of Financial Intermediation, 22 (2013), 663-687.

Constâncio, V. "Towards a European Banking Union.” Lecture held at the Duisenberg School of Finance, Amsterdam, 7 Sept. 2012.

Constâncio, V. "Towards the Banking Union." Speech at the 2nd FIN-FSA Conference on EU Regulation and Supervision: Banking and Supervision under Transformation. Organized by the Financial Supervisory Authority, Helsinki, 12 Feb. 2013.

Dinger, V., and F. Vallascas. "Do Banks Issue Equity When They Are Poorly Capitalized?" Journal of Financial and Quantitative Analysis (in press).

ECOFIN. "Proposal for a Council Regulation Conferring Specific Tasks on the European Central Bank Concerning Policies Relating to the Prudential Supervision of Credit Institutions." Brussels, 14 Dec. 2012.

European Banking Authority (EBA). "Future of the IRB Approach." Discussion Paper, EBA/DP/2015/01 (2015).

European Central Bank (ECB). Aggregate Report on the Comprehensive Assessment. Frankfurt am Main, Germany: European Central Bank (2014).

Fiordelisi F.; D. Marques-Ibanez; and P. Molyneux. "Efficiency and Risk in European Banking." Journal of Banking and Finance, 35 (2011), 1315-1326.

Harris, M., and A. Raviv. "How to Get Banks to Take Less Risk and Disclose Bad News." Journal of Financial Intermediation, 23 (2014), 437-470. 
Jayaratne, J., and P. E. Strahan. "The Finance-Growth Nexus: Evidence from Bank Branch Deregulation." Quarterly Journal of Economics, 111 (1996), 639-670.

Karolyi, G. A., and A. G. Taboada. "Regulatory Arbitrage and Cross-Border Bank Acquisitions." Journal of Finance, 70 (2015), 2395-2450.

Kroszner, R. S., and P. E. Strahan. "Regulatory Incentives and the Thrift Crisis: Dividends, Mutual-To-Stock Conversions, and Financial Distress." Journal of Finance, 51 (1996), $1285-1219$.

Lepetit, L.; N. Saghi-Zedek, and A. Tarazi. "Excess Control Rights, Bank Capital Structure Adjustments, and Lending.” Journal of Financial Economics, 115 (2015), 574-591.

Levine, R.; N. Loayza; and T. Beck. "Financial Intermediation and Growth: Causality and Causes." Journal of Monetary Economics, 46 (2000), 31-77.

Li, H.; D. K. Nandy; and G. S. Roberts. "Effects of Bank Regulation and Lender Location on Loan Spreads.”Journal of Financial and Quantitative Analysis, 47 (2012), 1247-1278.

Morgan, D. P.; S. Peristiani; and V. Savino. "The Information Value of the Stress Test.” Journal of Money, Credit and Banking, 46 (2014), 1479-1500.

Ongena, S.; A. Popov; and G. F. Udell. "When the Cat's Away the Mice Will Play': Does Regulation at Home Affect Bank Risk-Taking Abroad?" Journal of Financial Economics, 108 (2013), 727-750.

Peek, J.; E. S. Rosengren; and G. M. B. Tootell. "Is Bank Supervision Central to Central Banking?" Quarterly Journal of Economics, 114 (1999), 629-653.

Peltzman, S. "Toward a More General Theory of Regulation." Journal of Law and Economics, 19 (1976), 211-240.

Pigou, A. C.. The Economics of Welfare, 4th ed. London: Macmillan (1933). 
Rezende, M.. "The Effects of Bank Charter Switching on Supervisory Ratings." Finance and Economics Discussion Series 2014-20, Board of Governors of the Federal Reserve System, US (2014).

Rosen, R. J. "Is Three a Crowd? Competition Among Regulators in Banking." Journal of Money Credit and Banking, 35 (2003), 967-998.

Rosen, R. J. "Switching Primary Federal Regulators: Is It Beneficial for U. S. Banks?" Federal Reserve Bank of Chicago Economic Perspectives, 29 (2005), 16-33.

Stigler, G. “The Economic Theory of Regulation.” Bell Journal of Economics, 2 (1971), 3-21.

U.S. Financial Crisis Inquiry Commission. The Financial Crisis Inquiry Report. Washington D.C.: U.S. Government Printing Office (2011). 
Table 1

\section{Variable Definitions}

Table 1 defines the variables used in the paper and the sources of data.

\begin{tabular}{|c|c|c|c|}
\hline Variables & Symbol & Definition and Calculation Method & Source \\
\hline $\begin{array}{l}\text { Gross Loans } \\
\text { Growth }\end{array}$ & GL_GR & $\begin{array}{l}\text { The value of loans plus the reserves for loan losses in the current year over } \\
\text { the value of loans plus the reserves for loan losses in the previous year. }\end{array}$ & Bankscope \\
\hline Net Loans Growth & NL_GR & $\begin{array}{l}\text { The value of loans in the current year over the value of loans in the previous } \\
\text { year. }\end{array}$ & Bankscope \\
\hline $\begin{array}{l}\text { Reserves for Loan } \\
\text { Losses Growth }\end{array}$ & RLL_GR & $\begin{array}{l}\text { The value of the reserves for loan losses (i.e., the reserves against possible } \\
\text { losses on the lending portfolio) in the current year over the value of the } \\
\text { reserves for loan losses in the previous year. }\end{array}$ & Bankscope \\
\hline Capitalization & ETA & The ratio of equity to total assets. & Bankscope \\
\hline $\begin{array}{l}\text { Equity Capital } \\
\text { Growth }\end{array}$ & E_GR & $\begin{array}{l}\text { The value of equity in the current year over the value of equity in the } \\
\text { previous year. }\end{array}$ & Bankscope \\
\hline $\begin{array}{l}\text { Other Earning } \\
\text { Assets Growth }\end{array}$ & OEA_GR & $\begin{array}{l}\text { The growth of other earning assets (i.e., the sum of all of the bank's earning } \\
\text { assets excluding loans to consumers and to other banks) over two } \\
\text { consecutive years. }\end{array}$ & Bankscope \\
\hline Treatment Effect & $\mathrm{W}$ & $\begin{array}{l}\text { An indicator variable that takes the value of } 1 \text { if the bank is under direct } \\
\text { ECB supervision and if the time period is from the } 1^{\text {st }} \text { quarter } 2013 \text { onward } \\
\text { and } 0 \text { otherwise. }\end{array}$ & ECB \\
\hline Size & $\mathrm{S}$ & The natural log of total assets. & Bankscope \\
\hline Return on Assets & ROA & $\begin{array}{l}\text { The ratio of pre-tax profits to total assets. This variable measures bank } \\
\text { profitability while avoiding the effect of fiscal differences among countries. }\end{array}$ & Bankscope \\
\hline $\begin{array}{l}\text { Operational } \\
\text { Efficiency }\end{array}$ & $\mathrm{EFF}$ & $\begin{array}{l}\text { The ratio of operating costs to operating income. This variable measures the } \\
\text { bank's operational efficiency (i.e., the lower the cost to income ratio is, the } \\
\text { higher the level of operational efficiency will be). }\end{array}$ & Bankscope \\
\hline $\begin{array}{l}\text { Most Capitalized } \\
\text { Treated Banks }\end{array}$ & M_CAP & $\begin{array}{l}\text { An indicator variable that takes the value of } 1 \text { if a bank is in the top decile of } \\
\text { the distribution of common equity tier } 1 \text { (CET1) as calculated by the ECB in } \\
\text { the adverse stress-test scenario. }\end{array}$ & ECB \\
\hline $\begin{array}{l}\text { Less Capitalized } \\
\text { Treated Banks }\end{array}$ & L_CAP & $\begin{array}{l}\text { An indicator variable that takes the value of } 1 \text { if a bank had less than } 5.5 \% \\
\text { (i.e., less than the minimum requirement in the adverse scenario) of common } \\
\text { equity tier } 1 \text { at the end of } 2014 \text { after the CA in the adverse stress-test } \\
\text { scenario considered by the ECB. }\end{array}$ & ECB \\
\hline
\end{tabular}


Table 2:

\section{Summary Statistics}

Table 2 reports the summary statistics for all of the variables used in the paper. We use both "significant" and “non-significant" European banks (following the ECB's definition of significant) between 2011 and 2014. All of the variables are winsorized at the $1 \%$ level.

\begin{tabular}{|c|c|c|c|c|c|}
\hline & $\begin{array}{c}N \\
1\end{array}$ & $\begin{array}{c}\text { Mean } \\
2\end{array}$ & $\begin{array}{c}\text { Standard } \\
\text { Deviation } \\
3\end{array}$ & $\begin{array}{c}5^{\text {th }} \text { Percentile } \\
4\end{array}$ & $\begin{array}{c}95^{\text {th }} \text { Percentile } \\
5\end{array}$ \\
\hline$G L \_G R$ & 1,207 & 1.0360 & 0.1848 & 0.8416 & 1.3381 \\
\hline$N L \_G R$ & 1,207 & 1.0310 & 0.1882 & 0.8093 & 1.3338 \\
\hline RLL_GR & 971 & 1.1355 & 0.4359 & 0.6604 & 1.7767 \\
\hline ETA & 1,207 & 0.0975 & 0.0895 & 0.0271 & 0.2011 \\
\hline$E \_G R$ & 1,207 & 1.0697 & 0.2273 & 0.7633 & 1.4131 \\
\hline$O E A \_G R$ & 1,164 & 1.1785 & 0.6481 & 0.6298 & 2.1050 \\
\hline$S$ & 1,207 & 15.8581 & 2.1333 & 12.5532 & 19.7055 \\
\hline$E F F$ & 1,207 & 0.6856 & 0.2697 & 0.3234 & 1.1210 \\
\hline$R O A$ & 1,207 & 0.0031 & 0.0185 & -0.0351 & 0.0272 \\
\hline
\end{tabular}


Table 3:

\section{Difference in Means Before and After the SSM Launch}

Table 3 reports the difference in means between the group of treated banks and the group of untreated banks. The variable construction is reported in Table 1. The treatment period spans from 2013 to 2014, and the pretreatment period is 2011 to 2012 . Columns 1, 3, 5, and 7 present the difference in means between treated and untreated banks, and columns $2,4,6$, and 8 show the $p$-values from a $t$-test. $*$ and $* *$ indicate significance at the $5 \%$ and $1 \%$ levels, respectively.

\begin{tabular}{|c|c|c|c|c|c|c|c|c|}
\hline & \multicolumn{2}{|c|}{2011} & \multicolumn{2}{|c|}{2012} & \multicolumn{2}{|c|}{2013} & \multicolumn{2}{|c|}{2014} \\
\hline & Difference & p-value & Difference & $p$-value & Difference & $p$-value & Difference & p-value \\
\hline & 1 & 2 & 3 & 4 & 5 & 6 & 7 & 8 \\
\hline$G L \_G R$ & -0.0306 & 0.1061 & -0.0323 & 0.1377 & $-0.0853 * *$ & 0.0002 & $-0.0949 * *$ & 0.0003 \\
\hline$N L \_G R$ & -0.0314 & 0.1064 & -0.0346 & 0.1189 & $-0.0854 * *$ & 0.0002 & $-0.0928 * *$ & 0.0005 \\
\hline$R L L \_G R$ & -0.0389 & 0.4147 & 0.0351 & 0.5977 & -0.0816 & 0.1441 & $-0.2016^{* *}$ & 0.0004 \\
\hline ETA & $-0.0355^{* *}$ & 0.0004 & $-0.0353^{* *}$ & 0.0012 & $-0.0324 * *$ & 0.0018 & $-0.0291^{*}$ & 0.0186 \\
\hline$E \_G R$ & -0.0289 & 0.1760 & -0.0340 & 0.2740 & 0.0002 & 0.9947 & -0.0068 & 0.7837 \\
\hline$O E A \_G R$ & -0.1248 & 0.1221 & -0.0919 & 0.1929 & -0.1194 & 0.0828 & 0.0081 & 0.9348 \\
\hline$S$ & $2.9772 * *$ & 0.0000 & $2.9326^{* *}$ & 0.0000 & $2.8613 * *$ & 0.0000 & $2.8118^{* *}$ & 0.0000 \\
\hline$R O A$ & -0.0004 & 0.8495 & -0.0044 & 0.0827 & $-0.0053^{*}$ & 0.0155 & -0.0012 & 0.5397 \\
\hline$E F F$ & $-0.0919 * *$ & 0.0074 & -0.0588 & 0.0852 & $-0.0995 * *$ & 0.0021 & -0.0435 & 0.1185 \\
\hline
\end{tabular}




\section{Table 4}

\section{Banks' Reaction to the SSM Launch between 2011 and 2014: Loans}

Table 4 reports the results of a set of regressions in which the dependent variable refers to the yearly growth of (net) loans or the yearly growth of the reserves for loan losses. The dependent variables are total gross loan growth (GL_GR), the growth in the reserves for loan losses (RLL_GR), and net loan growth (NL_GR). The treatment variable $(W)$ is an indicator variable that takes the value of 1 if the bank is under direct ECB supervision and the time period is from 2013 onward and 0 otherwise. We control for the lagged value of bank size (S, i.e., the natural log of total assets); capitalization (ETA, i.e., the ratio of equity to total assets); operational efficiency (EFF, i.e., the ratio of operating costs to total operating income), and profitability (ROA, i.e., the ratio of pre-tax profits to total assets). * and ** indicate significance at the $5 \%$ and $1 \%$ levels, respectively. Robust standard errors in parentheses are clustered at the bank level.

\begin{tabular}{|c|c|c|c|c|c|c|c|c|c|}
\hline & $y=G L_{-} G R$ & $y=G L_{-} G R$ & $y=G L_{-} G R$ & $y=R L L \_G R$ & $y=R L L_{-} G R$ & $y=R L L_{-} G R$ & $y=N L_{-} G R$ & $y=N L_{-} G R$ & $y=N L_{-} G R$ \\
\hline & 1 & 2 & 3 & 4 & 5 & 6 & 7 & 8 & 9 \\
\hline \multirow[t]{2}{*}{$W$} & $-0.0503 * *$ & $-0.0445^{* *}$ & $-0.0463^{* *}$ & $-0.1914 * *$ & $-0.1713 * *$ & $-0.1441 * *$ & $-0.0460 * *$ & $-0.0404 *$ & $-0.0434 * *$ \\
\hline & $(0.0172)$ & $(0.0162)$ & $(0.0154)$ & $(0.0558)$ & $(0.0507)$ & $(0.0476)$ & $(0.0173)$ & $(0.0164)$ & $(0.0153)$ \\
\hline \multirow[t]{2}{*}{$S$} & $-0.1944 * *$ & $-0.2495 * *$ & $-0.2607 * *$ & -0.2854 & $-0.3904 *$ & $-0.5091 * *$ & $-0.1963^{* *}$ & $-0.2505^{* *}$ & $-0.2584^{* *}$ \\
\hline & $(0.0446)$ & $(0.0475)$ & $(0.0449)$ & $(0.1583)$ & $(0.1940)$ & $(0.1820)$ & $(0.0457)$ & $(0.0498)$ & $(0.0482)$ \\
\hline \multirow[t]{2}{*}{ ETA } & & $-1.0946^{*}$ & $-1.1696^{* *}$ & & -1.8499 & -2.3072 & & $-1.0940^{*}$ & $-1.1440 * *$ \\
\hline & & $(0.4421)$ & $(0.4170)$ & & (1.7772) & (1.7752) & & $(0.4533)$ & $(0.4318)$ \\
\hline \multirow[t]{2}{*}{ EFF } & & -0.0369 & -0.0094 & & -0.0683 & 0.0087 & & -0.0213 & 0.0030 \\
\hline & & $(0.0368)$ & $(0.0382)$ & & $(0.0914)$ & (0.0839) & & $(0.0410)$ & $(0.0433)$ \\
\hline \multirow[t]{2}{*}{ ROA } & & 0.9798 & 0.8272 & & 3.3807 & $4.3192 *$ & & 1.0572 & 0.9139 \\
\hline & & $(0.6802)$ & $(0.7237)$ & & (1.8647) & $(2.0483)$ & & $(0.6861)$ & $(0.7321)$ \\
\hline \multirow[t]{2}{*}{ CONS } & $4.1455^{* *}$ & $5.1470^{* *}$ & $5.3156^{* *}$ & $5.7869^{*}$ & $7.6887^{*}$ & $9.5765 * *$ & $4.1699 * *$ & $5.1472 * *$ & $5.2625^{* *}$ \\
\hline & $(0.7065)$ & $(0.7782)$ & $(0.7410)$ & $(2.5533)$ & $(3.2602)$ & (3.0658) & $(0.7247)$ & $(0.8193)$ & $(0.8006)$ \\
\hline Firm Fixed Effects & Yes & Yes & Yes & Yes & Yes & Yes & Yes & Yes & Yes \\
\hline \multirow{2}{*}{$\begin{array}{l}\text { Year Fixed Effects } \\
\text { Country-Year Fixed } \\
\text { Effects }\end{array}$} & Yes & Yes & No & Yes & Yes & No & Yes & Yes & No \\
\hline & No & No & Yes & No & No & Yes & No & No & Yes \\
\hline No. of obs. & 1,207 & 1,207 & 1,207 & 971 & 971 & 971 & 1,207 & 1,207 & 1,207 \\
\hline
\end{tabular}




\section{Table 5}

\section{Banks' Reaction to the SSM Launch between 2011 and 2014: Equity Capital}

Table 5 reports the results of a set of regressions in which the dependent variable is the ratio of equity to total assets (ETA, columns 1-3) or the equity capital annual growth (E_GR, columns 4-6). The treatment variable $(W)$ is an indicator variable that takes the value of 1 if the bank is under direct ECB supervision and the time period is from 2013 onward and 0 otherwise. We control for the lagged value of bank size (S, i.e., the natural $\log$ of total assets); operational efficiency (EFF, i.e., the ratio of operating costs to total operating income), and profitability (ROA, i.e., the ratio of pre-tax profits to total assets). ${ }^{*}$ and $* *$ indicate significance at the $5 \%$ and $1 \%$ levels, respectively. Robust standard errors in parentheses are clustered at the bank level.

\begin{tabular}{|c|c|c|c|c|c|c|}
\hline & $\begin{array}{c}y=E T A \\
1\end{array}$ & $\begin{array}{c}y=E T A \\
2\end{array}$ & $\begin{array}{c}y=E T A \\
3\end{array}$ & $\begin{array}{c}y=E_{-} G R \\
4\end{array}$ & $\begin{array}{c}y=E_{-} G R \\
5\end{array}$ & $\begin{array}{c}y=E_{-} G R \\
6\end{array}$ \\
\hline$W$ & $\begin{array}{l}0.0072 * \\
(0.0029)\end{array}$ & $\begin{array}{c}0.0078 * * \\
(0.0028)\end{array}$ & $\begin{array}{c}0.0073 * * \\
(0.0025)\end{array}$ & $\begin{array}{c}0.0301 \\
(0.0319)\end{array}$ & $\begin{array}{c}0.0187 \\
(0.0298)\end{array}$ & $\begin{array}{c}0.0005 \\
(0.0265)\end{array}$ \\
\hline S & $\begin{array}{l}-0.0105 \\
(0.0091)\end{array}$ & $\begin{array}{l}-0.0124 \\
(0.0090)\end{array}$ & $\begin{array}{l}-0.0095 \\
(0.0074)\end{array}$ & $\begin{array}{c}-0.2055 * * \\
(0.0554)\end{array}$ & $\begin{array}{c}-0.1679 * * \\
(0.0583)\end{array}$ & $\begin{array}{c}-0.1834 * * \\
(0.0578)\end{array}$ \\
\hline EFF & & $\begin{array}{c}0.0091 \\
(0.0063)\end{array}$ & $\begin{array}{c}0.0047 \\
(0.0074)\end{array}$ & & $\begin{array}{c}0.0111 \\
(0.0966)\end{array}$ & $\begin{array}{c}0.0485 \\
(0.0936)\end{array}$ \\
\hline ROA & & $\begin{array}{c}0.3096 * * \\
(0.0977)\end{array}$ & $\begin{array}{c}0.3558 * * \\
(0.0953)\end{array}$ & & $\begin{array}{c}-4.1620 * * \\
(1.0116)\end{array}$ & $\begin{array}{c}-3.5676^{* *} \\
(1.0251)\end{array}$ \\
\hline CONS & $\begin{array}{c}0.2674 \\
(0.1432)\end{array}$ & $\begin{array}{l}0.2892 * \\
(0.1404)\end{array}$ & $\begin{array}{l}0.2461 * \\
(0.1152)\end{array}$ & $\begin{array}{c}4.3341 * * \\
(0.8831)\end{array}$ & $\begin{array}{c}3.7473 * * \\
(0.9479)\end{array}$ & $\begin{array}{c}3.9738 * * \\
(0.9313)\end{array}$ \\
\hline Firm Fixed Effects & Yes & Yes & Yes & Yes & Yes & Yes \\
\hline $\begin{array}{l}\text { Year Fixed Effects } \\
\text { Country-Year } \\
\text { Fixed Effects }\end{array}$ & $\begin{array}{l}\text { Yes } \\
\text { No }\end{array}$ & Yes & No & Yes & Yes & $\begin{array}{l}\text { No } \\
\text { Yes }\end{array}$ \\
\hline No. of obs. & 1,207 & 1,207 & 1,207 & 1,207 & 1,207 & 1,207 \\
\hline
\end{tabular}




\section{Table 6}

\section{Banks' Reaction to the SSM Launch between 2011 and 2014: Most Capitalized and Less Capitalized Banks}

Table 6 reports the results of a set of regressions in which the dependent variable is the yearly variation in the lending activities of treated banks between 2011 and 2014. M_CAP measures whether a bank is well capitalized: It is an indicator variable that takes the value of 1 if a bank is in the $10^{\text {th }}$ decile of the distribution of CET1 (i.e.,. common equity tier 1) in the adverse stress-test scenario considered by the ECB in 2014, which is depicted in Figure 2. L_CAP measures whether a bank is less capitalized: It is an indicator variable that takes the value of 1 if a bank has less than $5.5 \%$ (i.e., the minimum capital requirement requested by the ECB in the adverse scenario) of CET1 in the 2014 adverse scenario considered by the ECB. The treatment variable $(W)$ is a dummy variable that takes the value of 1 if the bank is under direct ECB supervision and the time period is from 2013 onward and 0 otherwise. We control for the lagged value of bank size (S, i.e., the natural log of total assets); capitalization (ETA, i.e., the ratio of equity to total assets) (not in Models 4 and 5), operational efficiency (OPE, i.e., the ratio of operating costs to total operating income), and profitability (ROA, i.e., the ratio of pre-tax profits to total assets. * and $* *$ indicate significance at the $5 \%$ and $1 \%$ levels, respectively. Robust standard errors in parentheses are clustered at the bank level.

\begin{tabular}{|c|c|c|c|c|c|}
\hline & $\begin{array}{c}y=\mathrm{G} L_{-} G R \\
1\end{array}$ & $y=R_{2} L_{-} L_{-} G R$ & $\begin{array}{c}y=\mathrm{N} L_{-} G R \\
3\end{array}$ & $\begin{array}{c}y=\text { ETA } \\
4\end{array}$ & $y=\underset{5}{\text { E_GR }}$ \\
\hline \multirow[t]{2}{*}{$W$} & $-0.0446 * *$ & $-0.1824 * *$ & $-0.0388^{*}$ & $0.0061 *$ & 0.0112 \\
\hline & $(0.0166)$ & $(0.0530)$ & $(0.0166)$ & $(0.0027)$ & $(0.0309)$ \\
\hline \multirow[t]{2}{*}{$W \times$ M_CAP } & 0.0510 & $0.1638^{*}$ & 0.0422 & 0.0103 & -0.0488 \\
\hline & $(0.0354)$ & $(0.0818)$ & $(0.0352)$ & $(0.0101)$ & $(0.0267)$ \\
\hline \multirow[t]{2}{*}{$W \times$ L_CAP } & $-0.0764^{*}$ & -0.0246 & $-0.0907 * *$ & 0.0125 & 0.2017 \\
\hline & $(0.0297)$ & $(0.2006)$ & $(0.0310)$ & $(0.0129)$ & $(0.1477)$ \\
\hline \multirow[t]{2}{*}{ S } & $-0.2525 * *$ & $-0.3927^{*}$ & $-0.2538 * *$ & -0.0120 & $-0.1653 * *$ \\
\hline & $(0.0474)$ & $(0.1930)$ & $(0.0499)$ & $(0.0089)$ & $(0.0585)$ \\
\hline \multirow[t]{2}{*}{ ETA } & $-1.1511 * *$ & -1.9953 & $-1.1503^{*}$ & & \\
\hline & $(0.4435)$ & $(1.8080)$ & $(0.4567)$ & & \\
\hline \multirow[t]{2}{*}{ EFF } & -0.0411 & -0.0708 & -0.0260 & 0.0094 & 0.0213 \\
\hline & $(0.0375)$ & $(0.0939)$ & $(0.0418)$ & $(0.0064)$ & $(0.0975)$ \\
\hline \multirow[t]{2}{*}{ ROA } & 0.9138 & 3.3067 & 0.9875 & $0.3104 * *$ & $-3.9689 * *$ \\
\hline & $(0.6795)$ & (1.8792) & $(0.6849)$ & $(0.0987)$ & $(1.0245)$ \\
\hline \multirow[t]{2}{*}{ CONS } & $5.2026^{* *}$ & $7.7421^{*}$ & $5.2085^{* *}$ & $0.2834^{*}$ & $3.6991 * *$ \\
\hline & $(0.7771)$ & (3.2495) & $(0.8212)$ & $(0.1401)$ & $(0.9518)$ \\
\hline $\begin{array}{l}\text { Firm Fixed } \\
\text { Effects }\end{array}$ & Yes & Yes & Yes & Yes & Yes \\
\hline $\begin{array}{l}\text { Year Fixed } \\
\text { Effects }\end{array}$ & Yes & Yes & Yes & Yes & Yes \\
\hline No. of obs. & 1,207 & 971 & 1,207 & 1,207 & 1,207 \\
\hline
\end{tabular}




\section{Table 7}

\section{Banks' Reaction to the SSM Launch between 2011 and 2014: Country Heterogeneity}

Panel A in table 7 reports the results of a set of regressions in which the dependent variables are the growth of gross loans (GL_GR), loan loss reserves (RLL_GR), and net loans (NL_GR). In Panel B, the dependent variables are the equity capital ratio (ETA) and the annual growth of equity capital (E_GR). The treatment variable ( $W$ ) is a dummy variable that takes the value of 1 if the bank is under direct ECB supervision and the time period is from 2013 onward and 0 otherwise. The treatment variable is interacted with country indicator variables to identify the heterogeneity in the response to the SSM launch at the country level. We control for lagged values of bank size (S, i.e., the natural $\log$ of total assets); profitability (ROA, i.e., the ratio of pre-tax profits to total assets), capital levels (Panels A and B) (ETA, i.e., the ratio of equity to total assets), and operating efficiency (EFF, i.e., the ratio of operating costs to total operating income). $*$ and $* *$ indicate significance at the $5 \%$ and $1 \%$ levels, respectively. Robust standard errors in parentheses are clustered at the bank level. 
Panel A. Gross Loans Growth (GL_GR), Reserves for Loan Losses Growth (RLL_GR), and Net Loans Growth (NL GR).

\begin{tabular}{|c|c|c|c|c|c|c|c|c|c|c|c|c|}
\hline & $\begin{array}{c}y=G L_{-} G R \\
1\end{array}$ & $y=\underset{2}{G L_{-} G R \quad y=}$ & $y=\underset{G L}{G} G R \quad y=$ & $=\underset{4}{G L_{-} G R \quad y=}$ & $\begin{array}{l}R L L \_G R \\
5\end{array}$ & $\begin{array}{c}y=R L L_{-} G R \\
6\end{array}$ & $\begin{array}{c}y=R L L_{-} G R \\
7\end{array}$ & $\begin{array}{c}y=R L L_{-} G R \\
8\end{array}$ & $\begin{array}{c}y=N L_{-} G R \\
9\end{array}$ & $\begin{aligned} y= & N L_{-} G R \\
& 10\end{aligned}$ & $\begin{aligned} y= & N L_{-} G R \\
& 11\end{aligned}$ & $\begin{aligned} y= & N L_{-} G R \\
& 12\end{aligned}$ \\
\hline$W$ & $\begin{array}{c}-0.0444 * * \\
(0.0166)\end{array}$ & $\begin{array}{l}-0.0433 * \\
(0.0174)\end{array}$ & $\begin{array}{c}-0.0458 * * \\
(0.0162)\end{array}$ & $\begin{array}{l}-0.0426^{*} \\
(0.0171)\end{array}$ & $\begin{array}{c}-0.1877^{* *} \\
(0.0540)\end{array}$ & $\begin{array}{c}-0.1824 * * \\
(0.0555)\end{array}$ & $\begin{array}{c}-0.1264^{* *} \\
(0.0447)\end{array}$ & $\begin{array}{c}-0.2011^{* *} \\
(0.0554)\end{array}$ & $\begin{array}{c}-0.0401 * \\
(0.0167)\end{array}$ & $\begin{array}{l}-0.0388^{*} \\
(0.0174)\end{array}$ & $\begin{array}{c}-0.0445^{* * *} \\
(0.0165)\end{array}$ & $\begin{array}{c}-0.0369^{*} \\
(0.0171)\end{array}$ \\
\hline $\begin{array}{l}W \times \\
\text { France }\end{array}$ & $\begin{array}{l}-0.0014 \\
(0.0317)\end{array}$ & & & & $\begin{array}{l}0.1529 * * \\
(0.0451)\end{array}$ & & & & $\begin{array}{l}-0.0035 \\
(0.0315)\end{array}$ & & & \\
\hline $\begin{array}{l}\text { W } \times \\
\text { Germany }\end{array}$ & & $\begin{array}{l}-0.0054 \\
(0.0171)\end{array}$ & & & & $\begin{array}{c}0.0580 \\
(0.0655)\end{array}$ & & & & $\begin{array}{l}-0.0070 \\
(0.0170)\end{array}$ & & \\
\hline $\begin{array}{l}W \times \\
\text { Spain }\end{array}$ & & & $\begin{array}{c}0.0096 \\
(0.0389)\end{array}$ & & & & $\begin{array}{l}-0.3322 \\
(0.1688)\end{array}$ & & & & $\begin{array}{c}0.0309 \\
(0.0358)\end{array}$ & \\
\hline$W \times$ Italy & & & & $\begin{array}{l}-0.0136 \\
(0.0194)\end{array}$ & & & & $\begin{array}{c}0.1920 * * \\
(0.0602)\end{array}$ & & & & $\begin{array}{l}-0.0253 \\
(0.0207)\end{array}$ \\
\hline$S$ & $\begin{array}{c}-0.2495 * * \\
(0.0476)\end{array}$ & $\begin{array}{c}-0.2499 * * \\
(0.0477)\end{array}$ & $\begin{array}{c}-0.2497 * * \\
(0.0475)\end{array}$ & $\begin{array}{c}-0.2493 * * \\
(0.0476)\end{array}$ & $\begin{array}{l}-0.3930 * \\
(0.1933)\end{array}$ & $\begin{array}{l}-0.3861 * \\
(0.1944)\end{array}$ & $\begin{array}{c}-0.3859 * \\
(0.1950)\end{array}$ & $\begin{array}{c}-0.3954 * \\
(0.1927)\end{array}$ & $\begin{array}{c}-0.2505^{* *} \\
(0.0499)\end{array}$ & $\begin{array}{c}-0.2511 * * \\
(0.0501)\end{array}$ & $\begin{array}{c}-0.2511 * * \\
(0.0498)\end{array}$ & $\begin{array}{c}-0.2501 * * \\
(0.0500)\end{array}$ \\
\hline ETA & $\begin{array}{l}-1.0948 * \\
(0.4426)\end{array}$ & $\begin{array}{l}-1.0960 * \\
(0.4425)\end{array}$ & $\begin{array}{c}-1.0927^{*} \\
(0.4418)\end{array}$ & $\begin{array}{c}-1.1008 * \\
(0.4443)\end{array}$ & $\begin{array}{l}-1.8086 \\
(1.7701)\end{array}$ & $\begin{array}{l}-1.8369 \\
(1.7774)\end{array}$ & $\begin{array}{l}-1.9487 \\
(1.7899)\end{array}$ & $\begin{array}{l}-1.7284 \\
(1.7712)\end{array}$ & $\begin{array}{c}-1.0947 * \\
(0.4539)\end{array}$ & $\begin{array}{l}-1.0959 * \\
(0.4537)\end{array}$ & $\begin{array}{c}-1.0881 * \\
(0.4526)\end{array}$ & $\begin{array}{c}-1.1056^{*} \\
(0.4559)\end{array}$ \\
\hline EFF & $\begin{array}{l}-0.0369 \\
(0.0369)\end{array}$ & $\begin{array}{l}-0.0368 \\
(0.0369)\end{array}$ & $\begin{array}{l}-0.0367 \\
(0.0368)\end{array}$ & $\begin{array}{l}-0.0378 \\
(0.0373)\end{array}$ & $\begin{array}{l}-0.0687 \\
(0.0914)\end{array}$ & $\begin{array}{l}-0.0679 \\
(0.0912)\end{array}$ & $\begin{array}{l}-0.0704 \\
(0.0931)\end{array}$ & $\begin{array}{l}-0.0556 \\
(0.0918)\end{array}$ & $\begin{array}{l}-0.0213 \\
(0.0411)\end{array}$ & $\begin{array}{l}-0.0213 \\
(0.0411)\end{array}$ & $\begin{array}{l}-0.0210 \\
(0.0409)\end{array}$ & $\begin{array}{l}-0.0230 \\
(0.0415)\end{array}$ \\
\hline ROA & $\begin{array}{c}0.9799 \\
(0.6808)\end{array}$ & $\begin{array}{c}0.9848 \\
(0.6819)\end{array}$ & $\begin{array}{c}0.9930 \\
(0.6895)\end{array}$ & $\begin{array}{c}0.9738 \\
(0.6813)\end{array}$ & $\begin{array}{c}3.3342 \\
(1.8593)\end{array}$ & $\begin{array}{c}3.3364 \\
(1.8642)\end{array}$ & $\begin{array}{c}2.9007 \\
(1.8932)\end{array}$ & $\begin{array}{c}3.4595 \\
(1.8709)\end{array}$ & $\begin{array}{c}1.0576 \\
(0.6867)\end{array}$ & $\begin{array}{c}1.0636 \\
(0.6878)\end{array}$ & $\begin{array}{c}1.0997 \\
(0.6959)\end{array}$ & $\begin{array}{c}1.0460 \\
(0.6866)\end{array}$ \\
\hline CONS & $\begin{array}{c}5.1467 * * \\
(0.7790)\end{array}$ & $\begin{array}{c}5.1534 * * \\
(0.7815)\end{array}$ & $\begin{array}{c}5.1493 * * \\
(0.7784)\end{array}$ & $\begin{array}{c}5.1441 * * \\
(0.7800)\end{array}$ & $\begin{array}{l}7.7263^{*} \\
(3.2488)\end{array}$ & $\begin{array}{l}7.6175^{*} \\
(3.2670)\end{array}$ & $\begin{array}{l}7.6283^{*} \\
(3.2807)\end{array}$ & $\begin{array}{l}7.7490 * \\
(3.2368)\end{array}$ & $\begin{array}{c}5.1466^{* * *} \\
(0.8201)\end{array}$ & $\begin{array}{c}5.1554 * * \\
(0.8232)\end{array}$ & $\begin{array}{c}5.1546^{* * *} \\
(0.8186)\end{array}$ & $\begin{array}{c}5.1419 * * \\
(0.8219)\end{array}$ \\
\hline $\begin{array}{l}\text { Firm Fixed } \\
\text { Effects } \\
\text { Year Fixed } \\
\text { Effects }\end{array}$ & Yes & Yes & Yes & Yes & Yes & Yes & Yes & Yes & Yes & Yes & Yes & Yes \\
\hline No. of obs. & 1,207 & 1,207 & 1,207 & 1,207 & 971 & 971 & 971 & 971 & 1,207 & 1,207 & 1,207 & 1,207 \\
\hline
\end{tabular}


Panel B. Total Equity over Total Assets (ETA) and Equity Capital Growth (E GR)

\begin{tabular}{|c|c|c|c|c|c|c|c|c|}
\hline & $\begin{array}{c}y=E T A \\
1\end{array}$ & $\begin{array}{c}y=E T A \\
2\end{array}$ & $\begin{array}{c}y=E T A \\
3\end{array}$ & $\begin{array}{c}y=\underset{4}{E T A} \\
4\end{array}$ & $y={ }_{5}^{E-G R}$ & $\begin{array}{c}y=E_{-} G R \\
6\end{array}$ & $\begin{array}{c}y=E_{-} G R \\
7\end{array}$ & $\begin{array}{c}y=E_{-} G R \\
8\end{array}$ \\
\hline$W$ & $\begin{array}{c}0.0090 * * \\
(0.0029)\end{array}$ & $\begin{array}{c}0.0091 * * \\
(0.0032)\end{array}$ & $\begin{array}{l}0.0066^{*} \\
(0.0030)\end{array}$ & $\begin{array}{c}0.0091 * * \\
(0.0031)\end{array}$ & $\begin{array}{c}0.0211 \\
(0.0321)\end{array}$ & $\begin{array}{c}0.0296 \\
(0.0345)\end{array}$ & $\begin{array}{l}-0.0187 \\
(0.0277)\end{array}$ & $\begin{array}{c}0.0200 \\
(0.0330)\end{array}$ \\
\hline$W \times$ France & $\begin{array}{c}-0.0113 * * \\
(0.0044)\end{array}$ & & & & $\begin{array}{l}-0.0227 \\
(0.0336)\end{array}$ & & & \\
\hline$W \times$ Germany & & $\begin{array}{l}-0.0055 \\
(0.0030)\end{array}$ & & & & $\begin{array}{l}-0.0465 \\
(0.0374)\end{array}$ & & \\
\hline$W \times$ Spain & & & $\begin{array}{c}0.0091 \\
(0.0054)\end{array}$ & & & & $\begin{array}{c}0.2888 * * \\
(0.1032)\end{array}$ & \\
\hline$W \times$ Italy & & & & $\begin{array}{c}-0.0091 * * \\
(0.0032)\end{array}$ & & & & $\begin{array}{l}-0.0091 \\
(0.0454)\end{array}$ \\
\hline S & $\begin{array}{l}-0.0121 \\
(0.0090)\end{array}$ & $\begin{array}{l}-0.0127 \\
(0.0090)\end{array}$ & $\begin{array}{l}-0.0126 \\
(0.0090)\end{array}$ & $\begin{array}{l}-0.0120 \\
(0.0090)\end{array}$ & $\begin{array}{c}-0.1674 * * \\
(0.0586)\end{array}$ & $\begin{array}{c}-0.1707 * * \\
(0.0585)\end{array}$ & $\begin{array}{c}-0.1752 * * \\
(0.0576)\end{array}$ & $\begin{array}{c}-0.1675^{* *} * \\
(0.0586)\end{array}$ \\
\hline EFF & $\begin{array}{c}0.0090 \\
(0.0063)\end{array}$ & $\begin{array}{c}0.0091 \\
(0.0063)\end{array}$ & $\begin{array}{c}0.0092 \\
(0.0063)\end{array}$ & $\begin{array}{c}0.0085 \\
(0.0064)\end{array}$ & $\begin{array}{c}0.0110 \\
(0.0966)\end{array}$ & $\begin{array}{c}0.0111 \\
(0.0964)\end{array}$ & $\begin{array}{c}0.0150 \\
(0.0936)\end{array}$ & $\begin{array}{c}0.0104 \\
(0.0974)\end{array}$ \\
\hline ROA & $\begin{array}{c}0.3095 * * \\
(0.0973)\end{array}$ & $\begin{array}{c}0.3138 * * \\
(0.0978)\end{array}$ & $\begin{array}{c}0.3232 * * \\
(0.0987)\end{array}$ & $\begin{array}{c}0.3030 * * \\
(0.0981)\end{array}$ & $\begin{array}{c}-4.1622 * * \\
(1.0113)\end{array}$ & $\begin{array}{c}-4.1269 * * \\
(1.0021)\end{array}$ & $\begin{array}{c}-3.7312 * * \\
(0.9007)\end{array}$ & $\begin{array}{c}-4.1685^{* *} * \\
(1.0223)\end{array}$ \\
\hline CONS & $\begin{array}{l}0.2856 * \\
(0.1404)\end{array}$ & $\begin{array}{l}0.2946 * \\
(0.1414)\end{array}$ & $\begin{array}{l}0.2928 * \\
(0.1406)\end{array}$ & $\begin{array}{c}0.2840 * * \\
(0.1409)\end{array}$ & $\begin{array}{c}3.7400 * * \\
(0.9514)\end{array}$ & $\begin{array}{c}3.7924 * * \\
(0.9504)\end{array}$ & $\begin{array}{c}3.8606 * * \\
(0.9355)\end{array}$ & $\begin{array}{c}3.7421 * * \\
(0.9515)\end{array}$ \\
\hline $\begin{array}{l}\text { Firm Fixed } \\
\text { Effects } \\
\text { Year Fixed } \\
\text { Effects }\end{array}$ & Yes & Yes & Yes & Yes & Yes & Yes & Yes & Yes \\
\hline No. of obs. & 1,207 & 1,207 & 1,207 & 1,207 & 1,207 & 1,207 & 1,207 & 1,207 \\
\hline
\end{tabular}




\section{Table 8}

\section{Banks' Reaction to the SSM Launch between 2011 and 2014: the Effect on Banks' Other Earning Assets (Placebo Tests)}

Table 8 reports the results of a set of regressions in which the dependent variable is the annual growth of other earning assets (OEA_GR) between 2011 and 2014. The treatment variable $(W)$ is a dummy variable that takes the value of 1 if the bank is under direct ECB supervision and the time period is from 2013 onward and 0 otherwise. We control for the lagged values of bank size (S, i.e., the natural log of total assets); capital levels (ETA, i.e., the ratio of equity to total assets), profitability (ROA, i.e., the ratio of pre-tax profits to total assets), and operational efficiency (EFF, i.e., the ratio of operating costs to total operating income). * and ** indicate significance at the $5 \%$ and $1 \%$ levels, respectively. Robust standard errors in parentheses are clustered at the bank level.

\begin{tabular}{|c|c|c|c|}
\hline & $\begin{array}{c}y=O E A \_G R \\
1\end{array}$ & $\begin{array}{c}y=O E A \_G R \\
2\end{array}$ & $\begin{array}{c}y=O E A \_G R \\
3\end{array}$ \\
\hline$W$ & $\begin{array}{c}0.0396 \\
(0.0644)\end{array}$ & $\begin{array}{c}0.0386 \\
(0.0645)\end{array}$ & $\begin{array}{c}0.0517 \\
(0.0634)\end{array}$ \\
\hline S & $\begin{array}{c}-0.7443 * * \\
(0.1754)\end{array}$ & $\begin{array}{c}-0.7320 * * \\
(0.1862)\end{array}$ & $\begin{array}{c}-0.5977 * * \\
(0.1688)\end{array}$ \\
\hline ETA & & $\begin{array}{c}0.2548 \\
(1.5999)\end{array}$ & $\begin{array}{c}0.4785 \\
(1.5176)\end{array}$ \\
\hline $\mathrm{EFF}$ & & $\begin{array}{c}0.0338 \\
(0.1364)\end{array}$ & $\begin{array}{l}-0.1035 \\
(0.1554)\end{array}$ \\
\hline ROA & & $\begin{array}{c}0.2142 \\
(2.6856)\end{array}$ & $\begin{array}{l}-2.0780 \\
(2.9112)\end{array}$ \\
\hline CONS & $\begin{array}{c}13.0486 * * \\
(2.7937)\end{array}$ & $\begin{array}{c}12.8051 * * \\
(3.0198)\end{array}$ & $\begin{array}{c}10.7357 * * \\
(2.7016)\end{array}$ \\
\hline Firm Fixed Effects & Yes & Yes & Yes \\
\hline $\begin{array}{l}\text { Year Fixed Effects } \\
\text { Country-Year Fixed } \\
\text { Effects }\end{array}$ & Yes & Yes & No \\
\hline No. of obs. & 1,164 & 1,164 & 1,164 \\
\hline
\end{tabular}




\section{Table 9}

\section{Banks' Reaction to the SSM Launch between 2011 and 2012 (Placebo Tests)}

Panel A in table 9 reports the results of a set of regressions in which the dependent variables are the annual growth of gross loans (GL_GR), loan loss reserves (RLL_GR), and net loans (NL_GR). In Panel B, the dependent variables are the equity capital ratio (ETA) and the annual growth of equity capital (E_GR). We restrict our focus to the pretreatment period (2011-2012). The treatment variable (W 2012) is an indicator variable that takes the value of 1 if the bank will be under direct ECB supervision after the SSM launch and the year is 2012 and 0 otherwise. We control for the lagged values of bank size (S, i.e., the natural log of total assets), capital levels (Panel A) (ETA, i.e., the ratio of equity to total assets), profitability (ROA, i.e., the ratio of pre-tax profits to total assets), and operational efficiency (EFF, i.e., the ratio of operating costs to total operating income. $*$ and $* *$ indicate significance at the $5 \%$ and $1 \%$ levels, respectively. Robust standard errors in parentheses are clustered at the bank level.

Panel A. Loans: Loan Annual Growth (GL_GR), Growth of the Reserves for Loan Losses (RLL_GR), and Net Loan Annual Growth (NL_GR)

\begin{tabular}{lcccccc}
\hline & $y=$ GL_GR & $y=$ GL_GR & $y=$ RLL_GR & $y=$ RLL_GR & $y=$ NL_GR & $y=$ NL_GR \\
& 1 & 2 & 3 & 4 & 5 & 6 \\
\hline$W 2012$ & -0.0002 & -0.0017 & 0.0272 & 0.0169 & -0.0017 & -0.0021 \\
& $(0.0189)$ & $(0.0175)$ & $(0.0710)$ & $(0.0648)$ & $(0.0184)$ & $(0.0172)$ \\
S & $-0.3739^{* *}$ & $-0.3626^{* *}$ & -0.3754 & $-0.5814^{*}$ & $-0.3660^{* *}$ & $-0.3515^{* *}$ \\
\multirow{2}{*}{ ETA } & $(0.1022)$ & $(0.1047)$ & $(0.2607)$ & $(0.2838)$ & $(0.1061)$ & $(0.1081)$ \\
& $-2.1377^{*}$ & -1.9274 & -0.8995 & -1.4457 & -2.0662 & -1.8387 \\
EFF & $(1.0864)$ & $(1.0071)$ & $(1.6009)$ & $(1.8713)$ & $(1.1019)$ & $(1.0232)$ \\
& -0.0260 & -0.0169 & -0.0676 & 0.0022 & -0.0037 & -0.0005 \\
ROA & $(0.0532)$ & $(0.0614)$ & $(0.1006)$ & $(0.0956)$ & $(0.0604)$ & $(0.0680)$ \\
& 0.1749 & -0.1627 & 1.5449 & 2.0473 & 0.3877 & 0.0866 \\
CONS & $(1.2115)$ & $(1.2940)$ & $(2.4061)$ & $(2.7210)$ & $(1.1929)$ & $(1.2780)$ \\
& $7.1596^{* *}$ & $6.9563 * *$ & 7.3629 & $10.6800^{*}$ & $7.0041^{* *}$ & $6.7531^{* *}$ \\
& $(1.6814)$ & $(1.7235)$ & $(4.2286)$ & $(4.6091)$ & $(1.7487)$ & $(1.7838)$ \\
\hline Firm Fixed Effects & & & & & & \\
Year Fixed Effects & Yes & Yes & Yes & Yes & Yes & Yes \\
Country-Year Fixed Effects & No & Yes & Yes & No & Yes & No \\
No. of obs. & 601 & 601 & 480 & 480 & 601 & 601 \\
\hline
\end{tabular}


Panel B. Capital Levels: Equity over Total Assets (ETA) and Equity Capital Annual Growth (E_GR)

\begin{tabular}{lcccc}
\hline & $y=$ ETA & $y=$ ETA & $y=$ E_GR & $y=$ E_GR \\
& 1 & 2 & 3 & 4 \\
\hline$W 2012$ & -0.0021 & -0.0006 & -0.0133 & 0.0175 \\
& $(0.0024)$ & $(0.0022)$ & $(0.0348)$ & $(0.0330)$ \\
S & 0.0018 & 0.0068 & -0.1992 & -0.1813 \\
EFF & $(0.0155)$ & $(0.0140)$ & $(0.1422)$ & $(0.1322)$ \\
& $0.0126^{* *}$ & $0.0096^{*}$ & 0.1460 & 0.1538 \\
ROA & $(0.0046)$ & $(0.0047)$ & $(0.1497)$ & $(0.1476)$ \\
& $0.2581^{*}$ & 0.2820 & -1.8061 & -1.0201 \\
CONS & $(0.1071)$ & $(0.1449)$ & $(1.6604)$ & $(1.7592)$ \\
& 0.0578 & -0.0197 & 4.1482 & 3.8485 \\
& $(0.2451)$ & $(0.2205)$ & $(2.2115)$ & $(2.0508)$ \\
\hline Firm Fixed Effects & & & & \\
Year Fixed Effects & Yes & Yes & Yes & Yes \\
Country-Year Fixed & No & No & Yes & No \\
Effects & 601 & Yes & No & Yes \\
No. of obs. & & 601 & 601 & 601 \\
\hline
\end{tabular}




\section{Table 10}

\section{Banks' Reaction to the SSM Launch between 2011 and 2014: the Effect on Banks in Non-EMU Countries (placebo tests)}

Panel A in table 10 reports the results of a set of regressions in which the dependent variables are the annual growth of gross loans (GL_GR), net loans (NL_GR), and loan loss reserves. The dependent variables in Panel B are the equity capital ratio (ETA) and the annual growth of equity capital (E_GR). The treatment variable $(W)$ is a dummy that takes the value of 1 if the bank has at least one of the characteristics considered by the ECB for inclusion in the SSM from the 1st quarter of 2013 onward and 0 otherwise. Specifically, banks outside the Eurozone are considered to be treated if the total value of the bank's assets exceeds $€ 30$ billion, or the ratio of the bank's total assets to GDP of its country exceeds $20 \%$, or the bank is among the three largest such institutions in its country. We control for the lagged values of bank size (S, i.e., the natural log of total assets), capital levels (Panels A and B) (ETA, i.e., the ratio of equity to total assets), profitability (ROA, i.e., the ratio of pre-tax profits to total assets), and operational efficiency (EFF, i.e., the ratio of operating costs to total operating income). * and ** indicate significance at the 5\% and $1 \%$ levels, respectively. Robust standard errors in parentheses are clustered at the bank level.

Panel A. Loans: Gross Loan Growth (GL GR), Loan Loss Reserves Growth (RLL GR), and Net Loan Annual Growth (NL GR)

\begin{tabular}{|c|c|c|c|c|c|c|c|c|c|}
\hline & $y=G L_{-} G R$ & $y=G L_{-} G R$ & $y=G L_{-} G R$ & $y=R L L \_G R$ & $y=R L L \_G R$ & $y=R L L \_G R$ & $y=N L_{-} G R$ & $y=N L_{-} G R$ & $y=N L_{-} G R$ \\
\hline & 1 & 2 & 3 & 4 & 5 & 6 & 7 & 8 & 9 \\
\hline W & $\begin{array}{c}-0.0002 \\
(0.0209)\end{array}$ & $\begin{array}{c}-0.0016 \\
(0.0212)\end{array}$ & $\begin{array}{c}0.0012 \\
(0.0215)\end{array}$ & $\begin{array}{c}0.0147 \\
(0.0607)\end{array}$ & $\begin{array}{c}0.0138 \\
(0.0608)\end{array}$ & $\begin{array}{c}0.0189 \\
(0.0610)\end{array}$ & $\begin{array}{c}0.0001 \\
(0.0211)\end{array}$ & $\begin{array}{c}0.0009 \\
(0.0214)\end{array}$ & $\begin{array}{c}0.0049 \\
(0.0218)\end{array}$ \\
\hline S & $\begin{array}{c}-0.0774 * \\
(0.0386)\end{array}$ & $\begin{array}{c}-0.0670 \\
(0.0545)\end{array}$ & $\begin{array}{c}-0.0598 \\
(0.0557)\end{array}$ & $\begin{array}{c}0.0039 \\
(0.1111)\end{array}$ & $\begin{array}{c}0.0451 \\
(0.1723)\end{array}$ & $\begin{array}{c}-0.0154 \\
(0.1764)\end{array}$ & $\begin{array}{c}-0.0812 * \\
(0.0396)\end{array}$ & $\begin{array}{c}-0.0800 \\
(0.0550)\end{array}$ & $\begin{array}{l}-0.0707 \\
(0.0560)\end{array}$ \\
\hline ETA & & $\begin{array}{c}0.0541 \\
(0.2628)\end{array}$ & $\begin{array}{c}0.1366 \\
(0.2661)\end{array}$ & & $\begin{array}{c}0.4565 \\
(0.9918)\end{array}$ & $\begin{array}{c}0.0380 \\
(1.0053)\end{array}$ & & $\begin{array}{c}-0.0592 \\
(0.2528)\end{array}$ & $\begin{array}{c}0.0327 \\
(0.2601)\end{array}$ \\
\hline EFF & & $\begin{array}{c}0.0499 \\
(0.0463)\end{array}$ & $\begin{array}{c}0.0672 \\
(0.0505)\end{array}$ & & $\begin{array}{c}0.0563 \\
(0.1596)\end{array}$ & $\begin{array}{c}0.0778 \\
(0.1635)\end{array}$ & & $\begin{array}{c}0.0395 \\
(0.0439)\end{array}$ & $\begin{array}{c}0.0501 \\
(0.0480)\end{array}$ \\
\hline ROA & & $\begin{array}{c}0.2535 \\
(0.8878)\end{array}$ & $\begin{array}{c}-0.2240 \\
(0.8647)\end{array}$ & & $\begin{array}{c}0.6879 \\
(3.3440)\end{array}$ & $\begin{array}{c}0.1161 \\
(3.3131)\end{array}$ & & $\begin{array}{c}0.8711 \\
(0.8526)\end{array}$ & $\begin{array}{c}0.4175 \\
(0.8520)\end{array}$ \\
\hline CONS & $\begin{array}{c}2.2870 * * \\
(0.6001) \\
\end{array}$ & $\begin{array}{l}2.0846 * \\
(0.8692) \\
\end{array}$ & $\begin{array}{l}1.9534 * \\
(0.8883) \\
\end{array}$ & $\begin{array}{c}0.9727 \\
(1.7451) \\
\end{array}$ & $\begin{array}{c}0.2326 \\
(2.7482) \\
\end{array}$ & $\begin{array}{c}1.2196 \\
(2.8142) \\
\end{array}$ & $\begin{array}{c}2.3459 * * \\
(0.6163) \\
\end{array}$ & $\begin{array}{c}2.3034 * * \\
(0.8753) \\
\end{array}$ & $\begin{array}{r}2.1420^{*} \\
(0.8915) \\
\end{array}$ \\
\hline $\begin{array}{l}\text { Firm Fixed } \\
\text { Effects } \\
\text { Year Fixed }\end{array}$ & Yes & Yes & Yes & Yes & Yes & Yes & Yes & Yes & Yes \\
\hline $\begin{array}{l}\text { Effects } \\
\text { Country-Year } \\
\text { Fixed Effects }\end{array}$ & Yes & Yes & No & Yes & Yes & No & $\begin{array}{l}\text { Yes } \\
\text { No }\end{array}$ & Yes & No \\
\hline No. of obs. & 833 & 833 & 833 & 756 & 756 & 756 & 833 & 833 & 833 \\
\hline
\end{tabular}


Panel B. Capital Levels: Total Equity over Total Assets (ETA) and Equity Capital Annual Growth (E_GR)

\begin{tabular}{|c|c|c|c|c|c|c|}
\hline & $\begin{array}{c}y=E T A \\
1\end{array}$ & 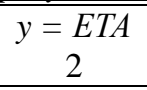 & $\begin{array}{c}y=\underset{E T A}{3} \\
\end{array}$ & $\begin{array}{c}y=E_{-} G R \\
4\end{array}$ & $y=\underset{5}{E} E_{-} G R$ & $\begin{array}{c}y=E_{6} G R \\
6\end{array}$ \\
\hline$W$ & $\begin{array}{c}-0.0014 \\
(0.0066)\end{array}$ & $\begin{array}{c}0.0003 \\
(0.0066)\end{array}$ & $\begin{array}{c}-0.0005 \\
(0.0069)\end{array}$ & $\begin{array}{c}0.0081 \\
(0.0224)\end{array}$ & $\begin{array}{c}0.0036 \\
(0.0232)\end{array}$ & $\begin{array}{c}0.0006 \\
(0.0228)\end{array}$ \\
\hline $\mathrm{S}$ & $\begin{array}{c}-0.0535 * \\
(0.0209)\end{array}$ & $\begin{array}{c}-0.0519 * * \\
(0.0191)\end{array}$ & $\begin{array}{c}-0.0521 * * \\
(0.0187)\end{array}$ & $\begin{array}{c}-0.1637 * * \\
(0.0335)\end{array}$ & $\begin{array}{c}-0.1854 * * \\
(0.0326)\end{array}$ & $\begin{array}{c}-0.1919 * * \\
(0.0342)\end{array}$ \\
\hline $\mathrm{EFF}$ & & $\begin{array}{l}-0.0087 \\
(0.0125)\end{array}$ & $\begin{array}{c}-0.0044 \\
(0.0126)\end{array}$ & & $\begin{array}{l}-0.0970 \\
(0.1620)\end{array}$ & $\begin{array}{l}-0.0476 \\
(0.1604)\end{array}$ \\
\hline $\mathrm{ROA}$ & & $\begin{array}{c}0.4862 \\
(0.3567)\end{array}$ & $\begin{array}{c}0.5179 \\
(0.3643)\end{array}$ & & $\begin{array}{c}-3.0229 * \\
(1.1896)\end{array}$ & $\begin{array}{c}-3.0198 * * \\
(1.1180)\end{array}$ \\
\hline CONS & $\begin{array}{c}0.9635 * * \\
(0.3273)\end{array}$ & $\begin{array}{c}0.9404 * * \\
(0.2980)\end{array}$ & $\begin{array}{c}0.9410 * * \\
(0.2916)\end{array}$ & $\begin{array}{c}3.6588 * * \\
(0.5246)\end{array}$ & $\begin{array}{c}4.0785 * * \\
(0.5871)\end{array}$ & $\begin{array}{c}4.1508 * * \\
(0.6059)\end{array}$ \\
\hline Firm FE & Yes & Yes & Yes & Yes & Yes & Yes \\
\hline Year FE & Yes & Yes & No & Yes & Yes & No \\
\hline Country-Year FE & No & No & Yes & No & No & Yes \\
\hline No. of obs. & 833 & 833 & 833 & 833 & 833 & 833 \\
\hline
\end{tabular}


Table 11

Difference between Treated and Untreated after Matching Banks before and after the SSM

Table 11 reports the average treatment effect on treated banks resulting from a nearest-neighbor matching analysis. Each treated bank is matched with its closest neighbor in terms of size in 2012 (i.e., the natural log of total assets in 2012), geographic location (a set of country indicator variables), and reporting year (a set of year indicator variables). We estimate the average treatment effect on treated banks using the bias-adjusted estimator defined in Abadie and Imbens (2006). Specifically, we match each treated bank based on the Euclidean distance from its closest neighbor and use bank size in 2012 and the country dummies to adjust for any potential bias.

Heteroskedasticity-consistent analytical standard errors proposed by Abadie and Imbens (2006) are used for the difference in means after matching. * and ** indicate significance at the 5\% and $1 \%$ levels, respectively.

\begin{tabular}{|c|c|c|c|c|}
\hline & \multicolumn{2}{|c|}{ 2011-2012 } & \multicolumn{2}{|c|}{ 2013-2014 } \\
\hline & $\begin{array}{l}\text { Difference in } \\
\text { Mean }\end{array}$ & Standard Errors & $\begin{array}{c}\text { Difference in } \\
\text { Mean }\end{array}$ & Standard Errors \\
\hline & 1 & 2 & 3 & 4 \\
\hline$G L_{-} G R$ & 0.0139 & $(0.0182)$ & $-0.0625^{*}$ & $(0.0283)$ \\
\hline RLL_GR & 0.0565 & $(0.1084)$ & $-0.1476^{* *}$ & $(0.0446)$ \\
\hline NL_GR & 0.0102 & $(0.0181)$ & $-0.0619 *$ & $(0.0288)$ \\
\hline ETA & 0.0023 & $(0.0064)$ & 0.0048 & $(0.0093)$ \\
\hline$E \_G R$ & 0.0250 & $(0.0638)$ & 0.0437 & $(0.0431)$ \\
\hline
\end{tabular}




\section{Table 12 \\ The Pivotal Moments in the Launch of the Single Supervisory Mechanism (SSM)}

Table 12 reports the most important events related to the SSM launch.

\begin{tabular}{|c|c|}
\hline Sept. 7, 2012 & $\begin{array}{l}\text { ECB vice president's speech at the Duisenberg School of Finance titled "Toward a European } \\
\text { Banking Union." }\end{array}$ \\
\hline Sept. 12, 2012 & $\begin{array}{l}\text { The European Commission adopts two proposals for the establishment of a Single } \\
\text { Supervisor Mechanism (SSM) for banks led by the European Central Bank (ECB). }\end{array}$ \\
\hline Dec. 14,2012 & $\begin{array}{l}\text { - The Economic and Financial Affairs Council (ECOFIN) reaches a landmark agreement } \\
\text { on the establishment of the SSM. } \\
\text { - Disclosure of the criteria adopted by the ECB to identify significant banks. }\end{array}$ \\
\hline Feb. 12, 2013 & $\begin{array}{l}\text { ECB vice president's speech at the Warwick Economics Summit titled "Financial Stability } \\
\text { Risks, Monetary Policy and the Need for Macro-Prudential Policy." }\end{array}$ \\
\hline Sept. 12, 2013 & ECB welcomes European Parliament vote to create the SSM. \\
\hline Oct. 23,2013 & ECB starts comprehensive assessment in advance of its supervisory role. \\
\hline Dec. 16,2013 & Danièle Nouy appointed as chair of the supervisory board. \\
\hline Jan. 09, 2014 & $\begin{array}{l}\text { New director general for supervision appoints four new directors general to take up positions } \\
\text { in early } 2014 \text {. }\end{array}$ \\
\hline Jan. 22, 2014 & ECB proposes candidate for vice chair of the SSM Supervisory Board. \\
\hline Feb. 03, 2014 & $\begin{array}{l}\text { ECB makes progress with asset quality review and confirms stress-test parameters for } \\
\text { comprehensive assessment. }\end{array}$ \\
\hline Feb. 07, 2014 & ECB launches public consultation on draft ECB SSM Framework Regulation. \\
\hline Mar. 07, 2014 & Supervisory board members appointed. \\
\hline Mar. 11, 2014 & ECB publishes manual for asset quality review. \\
\hline Apr. 25, 2014 & ECB publishes SSM Framework Regulation. \\
\hline Apr. 29, 2014 & $\begin{array}{l}\text { ECB to give banks six to nine months to cover capital shortfalls following comprehensive } \\
\text { assessment. }\end{array}$ \\
\hline May 27, 2014 & ECB launches public consultation on draft ECB regulation on supervisory fees. \\
\hline Jul. 17, 2014 & ECB publishes disclosure process for comprehensive assessment. \\
\hline Jul. 23, 2014 & Lithuania to join Euro area and the SSM on Jan. 1, 2015. \\
\hline Sept. 04, 2014 & ECB publishes final list of significant credit institutions. \\
\hline Sept. 08, 2014 & Members of the Administrative Board of Review appointed. \\
\hline Oct. 10,2014 & ECB discloses final results of comprehensive assessment. \\
\hline Oct. 22,2014 & Statement about media reports ahead of comprehensive assessment results. \\
\hline Oct. 23,2014 & $\begin{array}{l}\text { ECB launches public consultation on draft regulation on reporting of supervisory financial } \\
\text { information. }\end{array}$ \\
\hline Oct. 26, 2014 & ECB's in-depth review shows banks need to take further action. \\
\hline Nov. 04, 2014 & SSM starts. \\
\hline
\end{tabular}




\section{Figure 1}

\section{Loan Growth before the SSM Launch}

Figure 1 depicts the average growth of gross loans among treated banks (solid line) and untreated banks (dashed line). Loan growth is defined as the value of gross loans in year $t$ divided by the value of gross loans in year $t-1$. The growth of loans is calculated at the bank level and then averaged each year across the two groups of banks. These averages are calculated over the period preceding the treatment, from 2010 to 2012 .

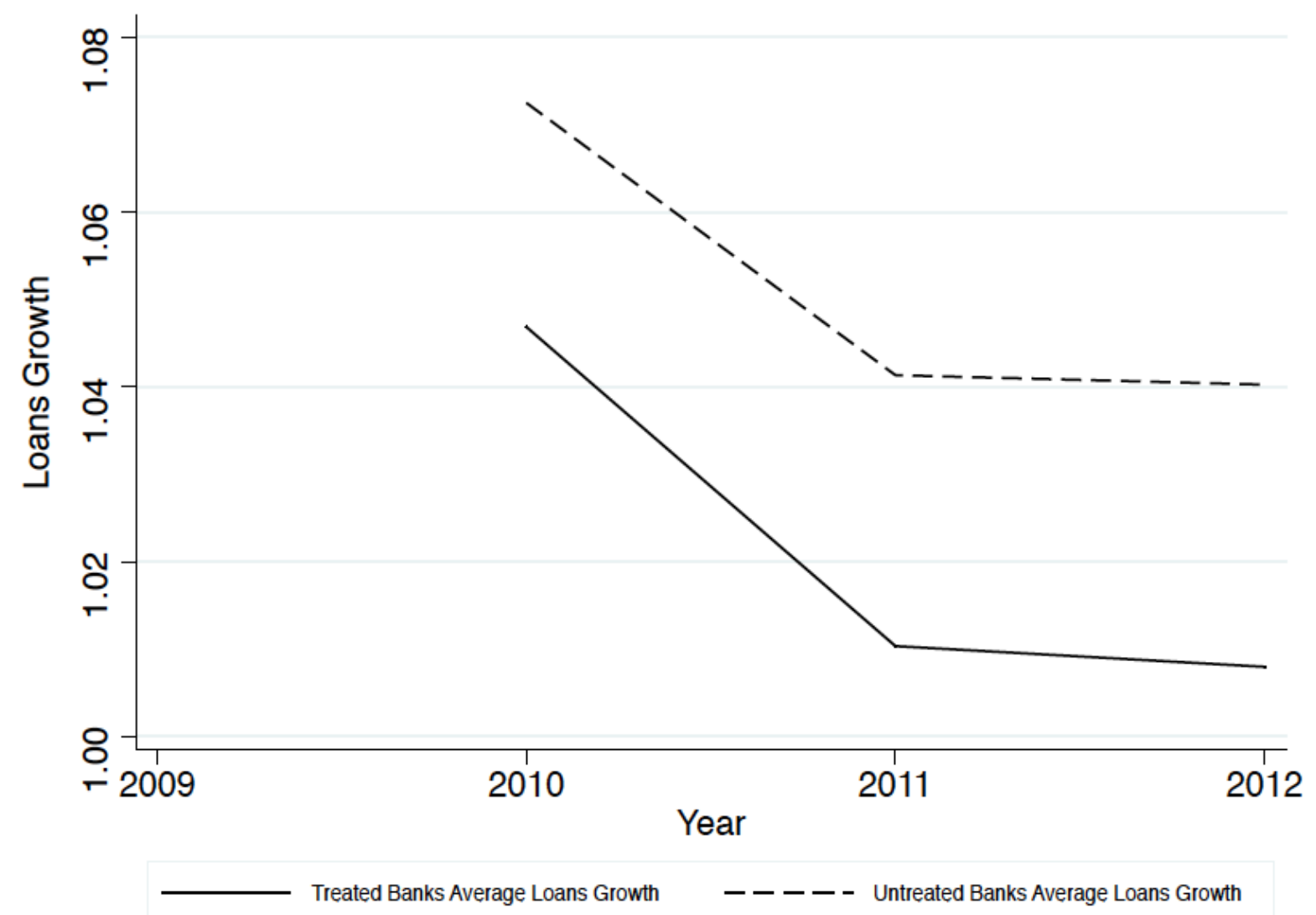




\section{Figure 2 \\ The Frequencies of the Common Equity Tier 1 Ratio (CET1) Calculated by the ECB in an Adverse Scenario in 2014}

The histogram in figure 2 reports the Common Equity Tier 1 (CET1) ratios of treated banks after the CA in 2014 in an adverse scenario. Source of data: ECB (2014). The dashed lines define the most capitalized treated banks (banks in the top decile of the CET1 distribution among treated banks in the adverse scenario, right line) and less capitalized treated banks (less than $5.5 \%$ CET1 in an adverse scenario, left vertical line).

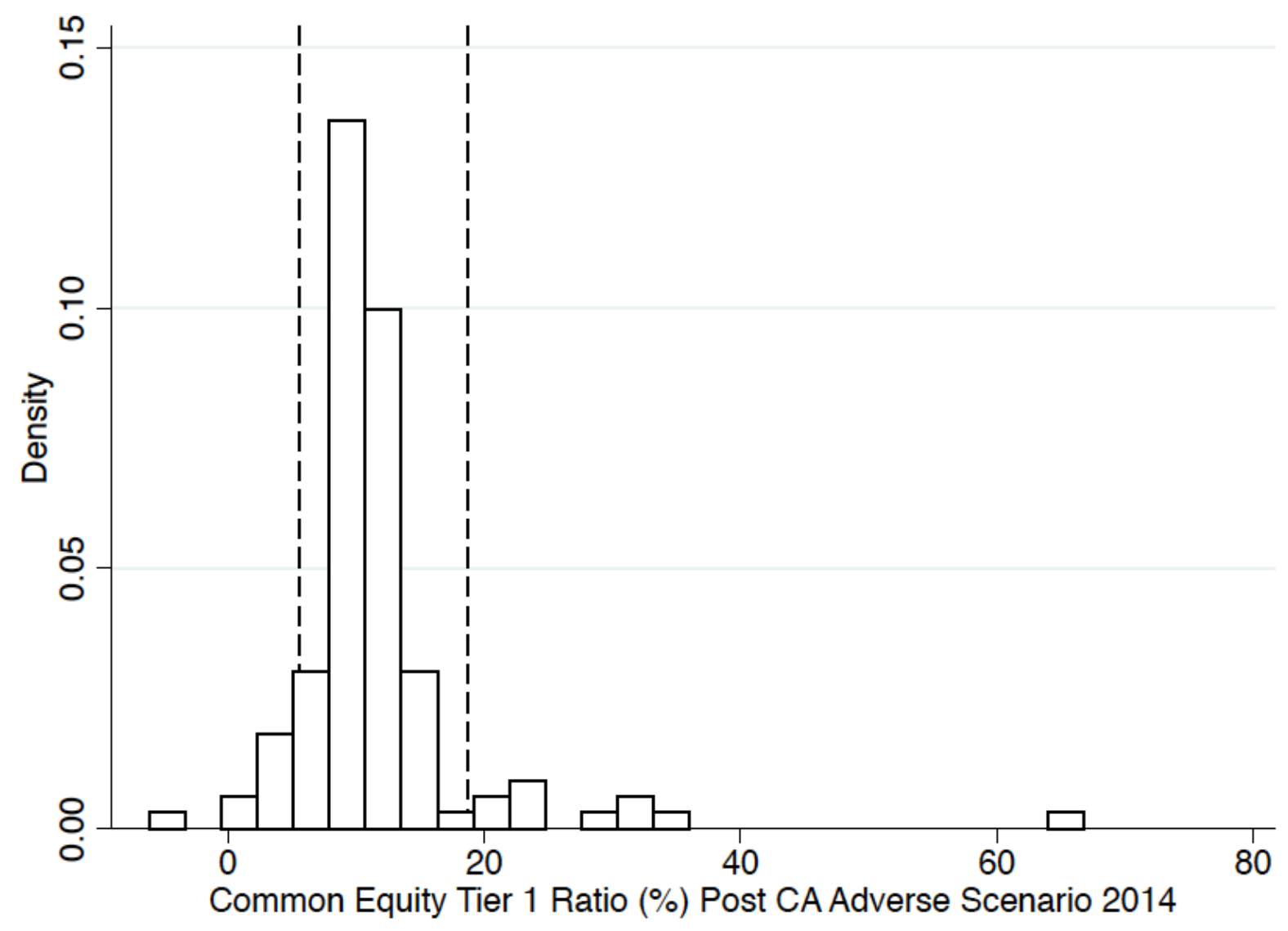


Figure 3

\section{Size Balance before and after Matching}

Figure 3 depicts kernel density plots of the balance in the natural logarithm of total assets before and after the nearest-neighbor matching.

Graph A. Size (S) Balance Plot Before and After Matching Y = GL_GR

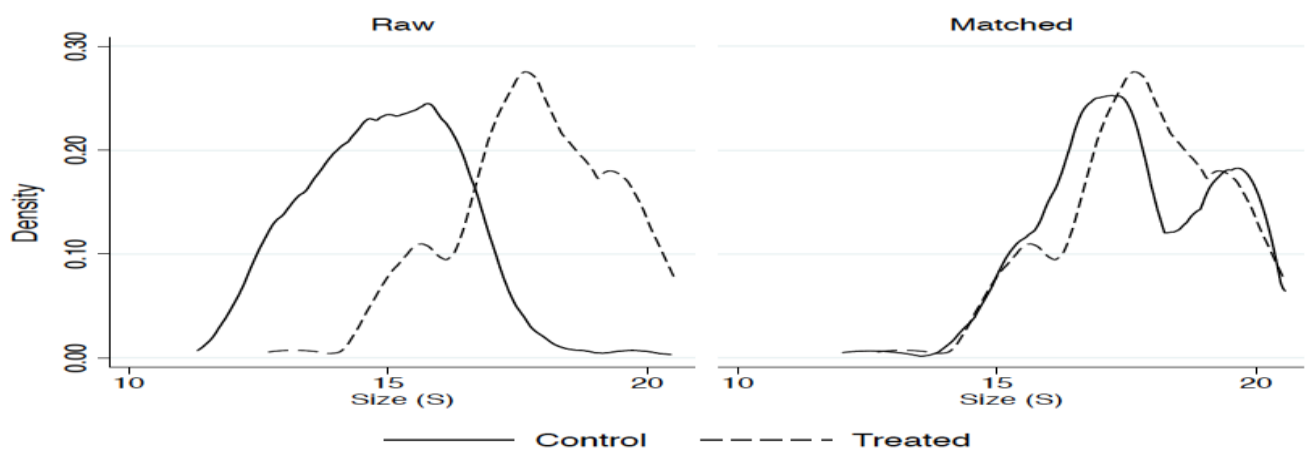

Graph B. Size (S) Balance Plot Before and After Matching Y = RLL_GR

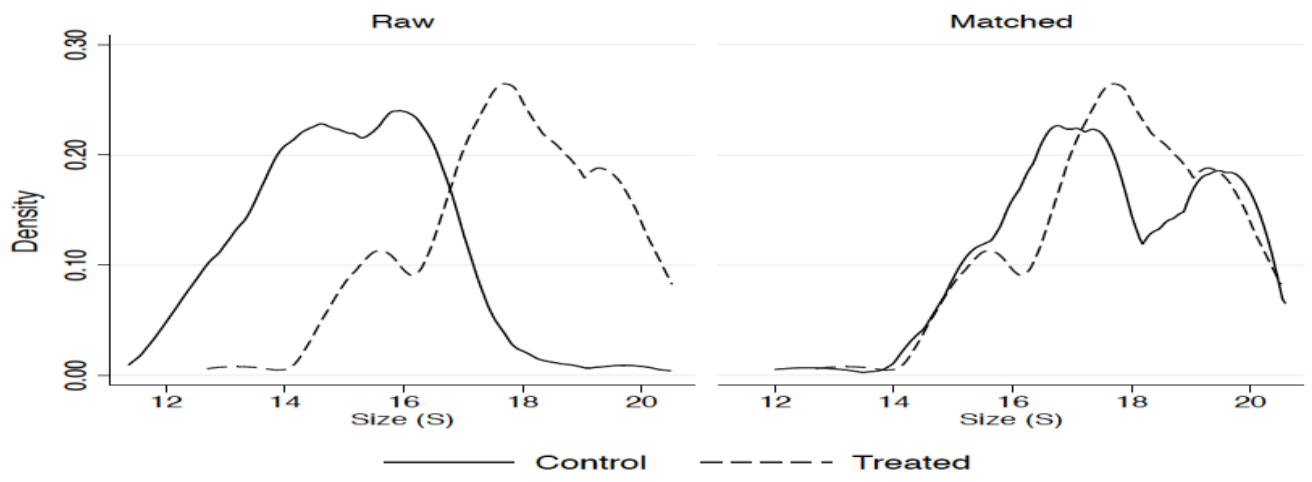

Graph C. Size (S) Balance Plot Before and After Matching Y = ETA

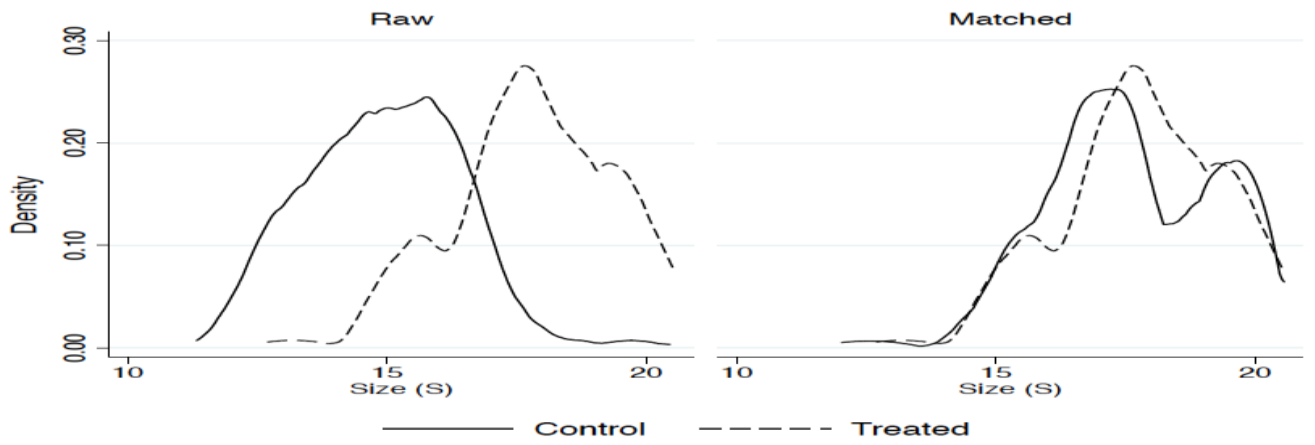


Graph D. Size (S) Balance Plot Before and After Matching Y = E_GR

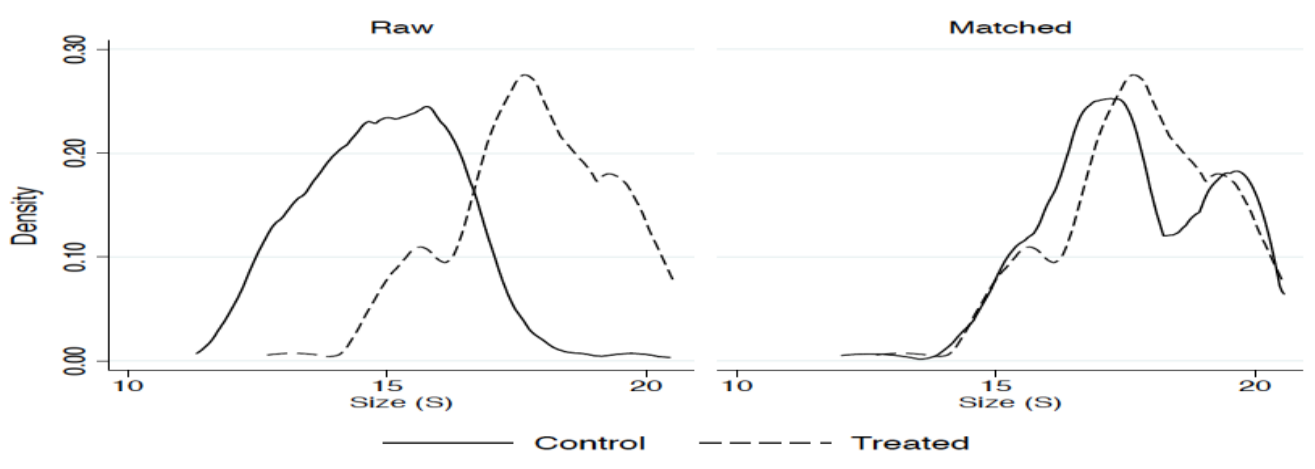

